Research Article

\title{
Characteristics and Meteorological Factors of Severe Haze Pollution in China
}

\author{
Chao He $\mathbb{D}^{1},{ }^{1}$ Song Hong $\left(\mathbb{D},{ }^{1}\right.$ Hang Mu ${ }^{D},{ }^{1}$ Peiyue Tu $\left(\mathbb{D},{ }^{2}\right.$ Lu Yang $\mathbb{D}^{1},{ }^{1}$ Biqin Ke, ${ }^{1}$ \\ and Jiayi Huang $\mathbb{B}^{3}$ \\ ${ }^{1}$ School of Resource and Environmental Sciences, Wuhan University, Wuhan 430079, China \\ ${ }^{2}$ Faculty of Resources and Environmental Science, Hubei University, Wuhan 430062, China \\ ${ }^{3}$ Woodsworth College, University of Toronto, M5S 1 A9 Toronto, Canada \\ Correspondence should be addressed to Jiayi Huang; evelynhuang719@gmail.com
}

Received 3 December 2020; Revised 13 May 2021; Accepted 5 June 2021; Published 22 June 2021

Academic Editor: Herminia García Mozo

Copyright (c) 2021 Chao He et al. This is an open access article distributed under the Creative Commons Attribution License, which permits unrestricted use, distribution, and reproduction in any medium, provided the original work is properly cited.

A severe haze pollution incident caused by unfavorable weather conditions and a northern air mass occurred in eastern, northern, northwestern, and southwestern China from January 15 to January 22, 2018. To comparatively analyze variations in $\mathrm{PM}_{2.5}$ pollution, hourly monitoring data and $24 \mathrm{~h}$ meteorological data were collected. Air quality observations revealed large spatiotemporal variation in $\mathrm{PM}_{2.5}$ concentrations in Handan, Zhengzhou, Xi'an, Yuncheng, Chengdu, Xiangyang, and Jinan. The daily mean $\mathrm{PM}_{2.5}$ concentrations ranged from 111.35 to $227.23 \mu \mathrm{g} \cdot \mathrm{m}^{-3}$, with concentration being highest in Zhengzhou. Hourly mean $\mathrm{PM}_{2.5}$ concentration presented multiple U-shaped curves, with higher values at night and lower values during the day. The ratios of $\mathrm{PM}_{2.5}$ to $\mathrm{PM}_{10}$ were large in target cities and the results of multiscale geographic weighted regression model (MGWR) and Pearson correlation coefficients showed that $\mathrm{PM}_{2.5}$ had a significant positive or negative correlation with $\mathrm{PM}_{10}, \mathrm{CO}, \mathrm{NO}_{2}$, and $\mathrm{SO}_{2}$. The concentration of $\mathrm{PM}_{2.5}$ was closely related to the combustion of fossil fuels and other organic compounds, indicating the large contribution of secondary aerosols to $\mathrm{PM}_{2.5}$ concentrations. The analysis of meteorological conditions showed that low temperature, low wind speed, and high relative humidity could aggravate the accumulation of regional pollutants in winter. Northwestern trajectory clusters were predominant contributions except in Jinan, and the highest $\mathrm{PM}_{2.5}$ concentrations in target cities were associated with short trajectory clusters in winter. The potential sources calculated by Weight Potential Source Contribution Function (WPSCF) and Weight ConcentrationWeighted Trajectory (WCWT) models were similar and the highest values of the WPSCF $(>0.5)$ and the WCWT $\left(>100 \mu \mathrm{g} \cdot \mathrm{m}^{-3}\right) \mathrm{were}$ mainly distributed in densely populated, industrial, arid, and semiarid regions.

\section{Introduction}

Severe haze pollution events occur frequently in winter in China and are dominated by $\mathrm{PM}_{2.5}$ (particulate matter with aerodynamic diameters no larger than $2.5 \mu \mathrm{m}$ ). Particulate matter pollution adversely affects human health and atmospheric visibility [1-3]. In addition, the direct and indirect radiation lead to climate change and disturb the structure and function of ecosystems [4, 5]. In densely populated and industrially developed areas, daily $\mathrm{PM}_{2.5}$ concentrations in winter frequently exceed the Class II category of the National Ambient Air Quality Standards (NAAQS, $75 \mu \mathrm{g} \mathrm{m}^{-3}$ ).
A serious haze pollution incident caused by unfavorable weather factors and a northern air mass occurred in eastern, northern, northwestern, and southwestern China from January 15 to January 22, 2018. The most polluted cities were Handan, Zhengzhou, Xi'an, Yuncheng, Chengdu, Xiangyang, and Jinan. Many studies have presented long-term measurements and analysis of $\mathrm{PM}_{2.5}$ concentrations in Handan, Zhengzhou, Xi'an, Yuncheng, Chengdu, Xiangyang, and Jinan during the last ten years. For example, Zhang et al. [6] reported that the chemical composition of $\mathrm{PM}_{10}, \mathrm{PM}_{2.5}$, and $\mathrm{PM}_{1}$ varied in Handan from November 16, 2015, to March 14, 2016, with serious pollution occurring during most of the cold season. A source analysis carried out 
by Jiang et al. [7] with a positive matrix method showed that the average annual concentrations of $\mathrm{PM}_{2.5}$ and $\mathrm{PM}_{10}$ were the highest in winter and the lowest in summer. Niu et al. [8] studied the temporal and spatial variation and chemical composition of $\mathrm{PM}_{2.5}$ in the Guanzhong Plain from March 2012 to March 2013. The average daily $\mathrm{PM}_{2.5}$ concentration was $134.7 \mu \mathrm{g} \cdot \mathrm{m}^{-3}$, exceeding the Class II category of the NAAQS.

Severe atmospheric pollution is closely related not only to emission sources but also to adverse meteorological conditions, terrain, pollutant transport pathways, and chemical reactions in atmosphere [9-11]. Human activities and meteorological conditions are the primary factors leading to variation in pollutant concentration $[12,13]$. For instance, if the aridity index and average annual temperature increased by $1 \%$, $\mathrm{PM}_{2.5}$ concentrations would increase by 66.9 and 35.7, respectively [14]. But $\mathrm{PM}_{2.5}$-heavy pollution is often accompanied by high relative humidity $[15,16]$. Moreover, stable weather conditions, low temperature, and wind speed can also aggravate the accumulation of regional pollutants in winter. $\mathrm{PM}_{2.5}$ and $\mathrm{PM}_{10}$ become very high in the postmonsoon season in Kolkata; PM concentrations are observed to be the lowest during the monsoon seasons; meanwhile, the $\mathrm{NO}_{2}$ and $\mathrm{CO}$ concentrations demonstrate similar seasonal fluctuations [17].

Long-distance transportation among regions also plays an important role in $\mathrm{PM}_{2.5}$ pollution. In recent years, the Hybrid Single-Particle Lagrangian Integrated Trajectory (HYSPLIT) model and the TrajStat model [18] have become critical tools for studying long-distance transport and potential pollutant sources. Many scholars have traced the transmission path of $\mathrm{CO}, \mathrm{O}_{3}, \mathrm{SO}_{2}, \mathrm{PM}_{2.5}, \mathrm{PM}_{10}$, and other gaseous pollutants using HYSPLIT and TrajStat models [19-21]. Filonchyk and Yan [22] quantitatively investigated the causes of severe haze during spring and winter seasons in northwest China based on the backward trajectory and the HYSPLIT model. The results showed that the movement of air masses in the north, northwest, and west of China is the main cause of haze during spring and winter in northwest China. However, these studies only focused on the transport direction and passing area in the near surface and did not carry out statistical analyses of $\mathrm{PM}_{2.5}$ concentrations in backward trajectories and clustering trajectories.

Previous studies have focused on the spatial and temporal distribution of $\mathrm{PM}_{2.5}$ in a single city as well as influence factors and potential sources, which often neglects the impact of pollutant transport among cities. To better understand the impact of pollutant transport in different cities, real-time pollutant data and meteorological data of major Chinese cities were collected in this research during the haze period in January 2018. We investigated the correlations between air pollution and meteorological conditions and their spatial variation. We computed Weight Potential Source Contribution Function (WPSCF) and Weight ConcentrationWeighted Trajectory (WCWT) models to quantify potential source distributions in different cities. This research aimed to provide a reference for the local government to manage sudden air pollution incidents, propose a method for studying long-distance transport, and identify potential sources of air pollutants in $\mathrm{PM}_{2.5}$ haze pollution.

\section{Methods}

2.1. Air Quality Observations and Data Quality. Observational pollution data from January 15 to January 22, 2018, were used in this study. Real-time data were provided by the China National Environmental Monitoring Center (http://www.cnemc.cn) after being validated, with hourly concentrations of six major pollutants: $\mathrm{PM}_{2.5}, \mathrm{PM}_{10}$, sulfur dioxide $\left(\mathrm{SO}_{2}\right)$, nitrogen dioxide $\left(\mathrm{NO}_{2}\right)$, carbon monoxide $(\mathrm{CO})$, and ozone $\left(\mathrm{O}_{3}\right)$. We calculated daily mean concentrations of $\mathrm{PM}_{2.5}$ in seven cities (Handan, Zhengzhou, Xi'an, Yuncheng, Chengdu, Xiangyang, and Jinan) (Figure 1(b)). We used the threshold of $75 \mu \mathrm{g} \cdot \mathrm{m}^{-3}$ as the highest $\mathrm{PM}_{2.5}$ concentration for acceptable air quality according to the Class II category of the NAAQS (GB3095-2012). Mean PM 2.5 concentration in 30 provincial capitals and seven cities was calculated with data from 302 monitoring sites during the pollution period (Figure 1(c)). As shown in Table 1, each city had set up several air quality monitoring sites, most of which were located in urban areas and some in suburban and rural areas as background sites. Daily mean $\mathrm{PM}_{2.5}$ concentrations were calculated when valid data were available for more than $20 \mathrm{~h}$ during the day and values were greater than zero [23]. We adopted the same method as the government reports daily concentrations of air pollutants to the public, averaging the concentrations at all sites in each city to represent the daily mean concentration of the city.

2.2. Meteorological Data. Hourly meteorological data from January 15 to January 22, 2018, were obtained from the National Meteorological Information Center of the China Meteorological Administration (http://data.cma.cn/) and used to analyze the relationship between meteorological conditions and air pollution. Hourly meteorological data included temperature, relative humidity, 2 min wind speed, 2 min wind direction, and sea-level pressure. Mean values of each meteorological parameter were calculated using data for all monitoring sites in a region.

2.3. Multiscale Geographically Weighted Regression. MGWR is a significant improvement on GWR because it allows one to study relationships at varying spatial scales and covariate-specific bandwidths to be optimized [24]. MGWR can be defined as

$$
\begin{aligned}
y\left(\mathrm{PM}_{2.5}\right)= & \beta_{\mathrm{bw} 1}\left(u_{i}, v_{i}\right) \mathrm{PM}_{10 i}+\beta_{\mathrm{bw} 2}\left(u_{i}, v_{i}\right) \mathrm{SO}_{2 i} \\
& +\beta_{\mathrm{bw} 3}\left(u_{i}, v_{i}\right) \mathrm{CO}_{i} \\
& +\beta_{\mathrm{bw} 4}\left(u_{i}, v_{i}\right) \mathrm{NO}_{2 i}+\beta_{\mathrm{bw} 5}\left(u_{i}, v_{i}\right) \mathrm{O}_{3-8 \mathrm{~h} i}+\varepsilon_{i},
\end{aligned}
$$

where $\left(u_{i}, v_{i}\right)$ represents the geographical coordinates of $i$ city, $\beta_{\mathrm{bw} i}$ is the regression coefficient, and $\varepsilon_{i}$ represents a random error term. We used the MGWR2.2 software to undertake all calibrations (https://sgsup.asu.edu/sparc/ mgwr). The spatial kernel function type is Bisquare, the bandwidth search type is Golden, and the parameter initialization type is GWR estimation [25]. 

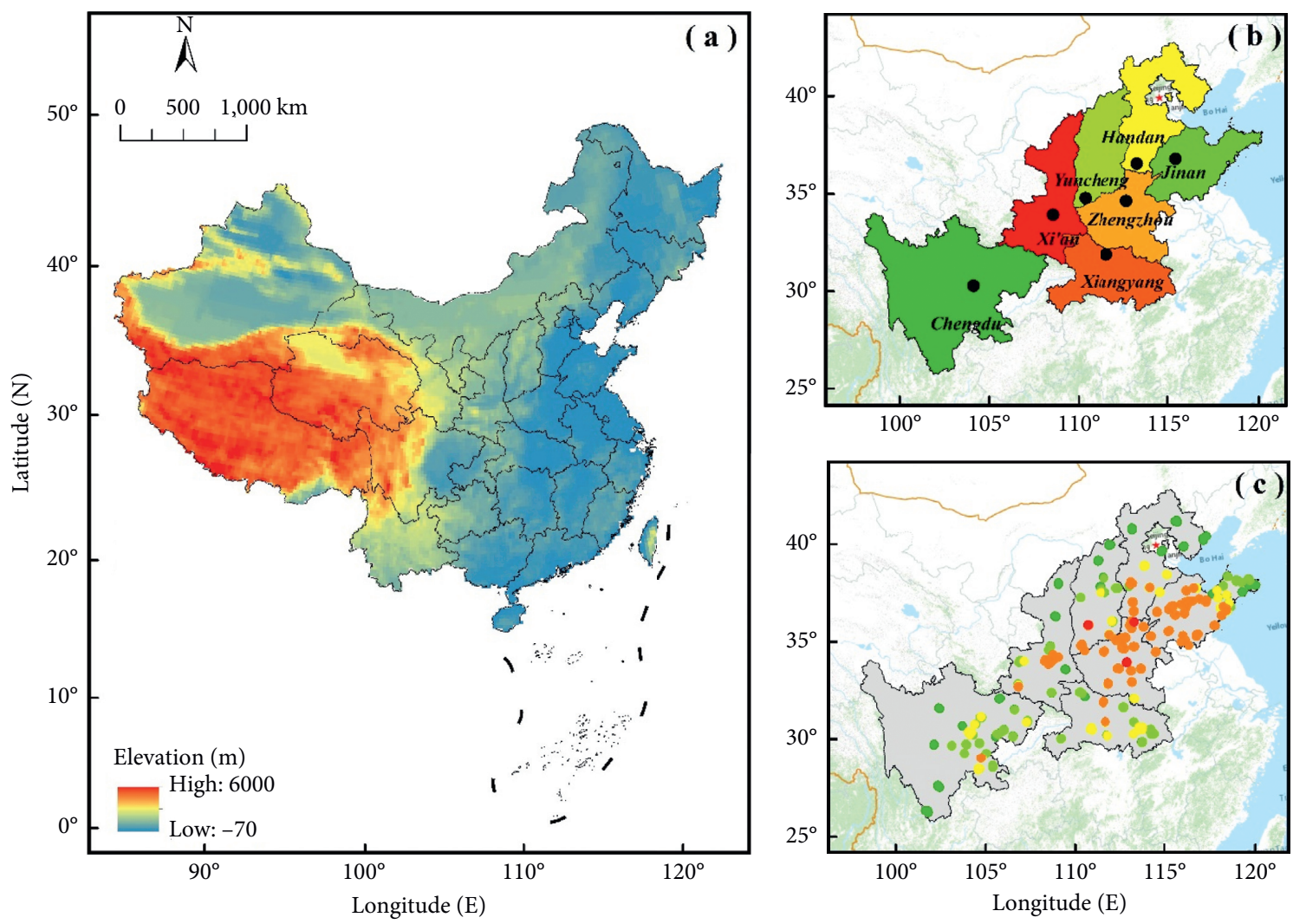

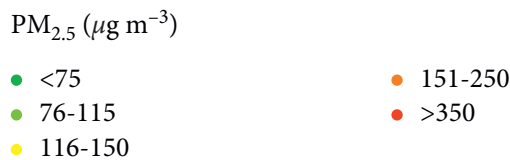

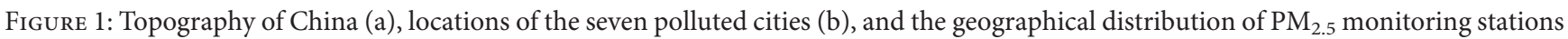
in this study (c).

2.4. Trajectory Data. In this study, $72 \mathrm{~h}$ backward trajectories arriving at the centers of Handan $\left(114.51^{\circ} \mathrm{E}, 36.62^{\circ} \mathrm{N}\right)$, Zhengzhou $\left(113.64^{\circ} \mathrm{E}, 34.75^{\circ} \mathrm{N}\right)$, Xi' an $\left(108.95^{\circ} \mathrm{E}, 34.27^{\circ} \mathrm{N}\right)$, Chengdu $\left(104.07^{\circ} \mathrm{E}, 30.66^{\circ} \mathrm{N}\right)$, Yuncheng $\left(111.02^{\circ} \mathrm{E}, 35.04^{\circ} \mathrm{N}\right)$, Xiangyang $\left(112.17^{\circ} \mathrm{E}, 32.07^{\circ} \mathrm{N}\right)$, and Jinan $\left(116.99^{\circ} \mathrm{E}, 36.67^{\circ} \mathrm{N}\right)$ were calculated every $6 \mathrm{~h}$ (at $00 \mathrm{~h}, 06 \mathrm{~h}, 12 \mathrm{~h}$, and $18 \mathrm{~h}$ Coordinated Universal Time) during the pollution period. Data were obtained from the National Centers for Environmental Prediction (NCEP) reanalysis data and the HYSPLIT model (version 4.9) developed by the National Oceanic and Atmospheric Administration Air Resources Laboratory (NOAA ARL, https://ready.arl.noaa.gov/HYSPLIT.php).

2.5. Inverse Distance Weighted Interpolation. The inverse distance weighted interpolation method is based on the principle of similarity. The spatial variation of $\mathrm{PM}_{2.5}$ mass concentration in China during the pollution period was drawn in ArcGIS 10.3. We used the coordinate information of 1,436 air quality monitoring stations in 338 cities as the "input point feature" and used daily $\mathrm{PM}_{2.5}$ mass concentration data at each site as the $Z$ value field. We set the maximum number of adjacent features and the minimum number of adjacent features to 15 and 10, respectively.
2.6. Backward Trajectory Statistics and Calculation. Trajectory cluster calculation was carried out with TrajStat [26] http://www.meteothinker.com/downloads/index.html). TrajStat provides two clustering options, Euclidean distance or angle distance. In this study, we used angle distance as we intended to use the backward trajectories to determine how the air mass reached the center of the monitoring point. The angular distance between two backward trajectories is defined as

$$
D_{12}=\frac{1}{n} \sum_{i=1}^{n} \cos ^{-1}\left(0.5 \frac{\left(A_{i}+B_{i}-C_{i}\right)}{\sqrt{A_{i} B_{i}}}\right),
$$

where $\quad A_{i}=\left(X_{1}(i)-X_{0}\right)^{2}+\left(Y_{1}(i)-Y_{0}\right)^{2}, \quad B_{i}=\left(X_{2}(i)\right.$ $\left.-X_{0}\right)^{2}+\left(Y_{2}(i)-Y_{0}\right)^{2}$, and $C_{i}=\left(X_{2}(i)-X_{1}(i)\right)^{2}+\left(Y_{2}(i)\right.$ $\left.-Y_{1}(i)\right)^{2} \cdot D_{12}$ is the mean angle between two backward trajectories. The variables $X_{0}$ and $Y_{0}$ define the position of the study site.

2.7. WPSCF Analysis. The Potential Source Contribution Function (PSCF) algorithm identifies source regions based on airflow trajectories analysis and has been widely used to identify potential source areas for high-concentration pollutants at receptor sites [27]. The area covered by the 
TABLE 1: Longitude-latitude, regional category, number of background sites, and available monitoring sites of 30 provincial capitals in China.

\begin{tabular}{|c|c|c|c|c|c|}
\hline City name & Longitude & Latitude & Region & Background sites & Available sites \\
\hline Changsha (CS) & 112.98 & 28.20 & Central & 1 & 10 \\
\hline Wuhan (WH) & 114.29 & 30.57 & Central & 1 & 11 \\
\hline Zhengzhou (ZZ) & 113.65 & 34.76 & Central & 1 & 9 \\
\hline Fuzhou (FZ) & 119.30 & 26.08 & East & 1 & 7 \\
\hline Hangzhou (HZ) & 120.16 & 30.27 & East & 1 & 11 \\
\hline Hefei (HF) & 117.28 & 31.86 & East & 1 & 10 \\
\hline Jinan (JN) & 117.01 & 36.67 & East & 4 & 15 \\
\hline Nanchang (NC) & 115.90 & 28.68 & East & 1 & 9 \\
\hline Nanjing (NJ) & 118.77 & 32.05 & East & 4 & 13 \\
\hline Shanghai (SH) & 121.47 & 31.24 & East & 1 & 10 \\
\hline Beijing (BJ) & 116.38 & 39.92 & North & 1 & 12 \\
\hline Hohhot (HT) & 111.66 & 40.82 & North & 0 & 8 \\
\hline Shijiazhuang (SJZ) & 114.49 & 38.05 & North & 1 & 9 \\
\hline Taiyuan (TY) & 112.57 & 37.87 & North & 2 & 10 \\
\hline Tianjin (TJ) & 117.20 & 39.13 & North & 1 & 15 \\
\hline Changchun (CC) & 125.32 & 43.89 & Northeast & 1 & 10 \\
\hline Harbin (HB) & 126.64 & 45.74 & Northeast & 1 & 13 \\
\hline Shengyang (SY) & 123.41 & 41.80 & Northeast & 3 & 13 \\
\hline Lanzhou (LZ) & 91.13 & 29.66 & Northwest & 1 & 5 \\
\hline Urumqi (UQ) & 87.61 & 43.79 & Northwest & 1 & 8 \\
\hline Xi'an (XA) & 108.95 & 34.26 & Northwest & 1 & 13 \\
\hline Xining (XN) & 101.79 & 36.61 & Northwest & 2 & 5 \\
\hline Yinchuan (YC) & 106.27 & 38.47 & Northwest & 1 & 6 \\
\hline Guangzhou (GZ) & 113.26 & 23.12 & South & 1 & 12 \\
\hline Nanning (NN) & 108.31 & 22.81 & South & 1 & 8 \\
\hline Chengdu (CD) & 104.08 & 30.66 & Southwest & 1 & 9 \\
\hline Chongqin (CQ) & 106.51 & 29.56 & Southwest & 1 & 17 \\
\hline Guiyang (GY) & 106.71 & 26.58 & Southwest & 1 & 10 \\
\hline Kunmin (KM) & 102.70 & 25.04 & Southwest & 2 & 8 \\
\hline Lhasa (LS) & 103.75 & 36.07 & Southwest & 0 & 6 \\
\hline
\end{tabular}

backward trajectory is divided into equal $i \times j$ grid cells. The PSCF value for the $i j^{\text {th }}$ cell is defined as

$$
\operatorname{PSCF}_{i j}=\frac{m_{i j}}{n_{i j}},
$$

where $n_{i j}$ is the total number of trajectory endpoints that fall in the $i{ }^{\text {th }}$ grid cells and $m_{i j}$ is the total number of trajectory endpoints for which the monitored pollutant concentration exceeds a threshold value in the cells (Kong et al., 2013; [28]). In this study, the grid cell size was $0.5^{\circ} \times 0.5$ latitude-longitude and we defined $75 \mu \mathrm{g} \cdot \mathrm{m}^{-3}$ as the threshold value of $\mathrm{PM}_{2.5}$ mass concentration. To account for uncertainty, PSCF values were multiplied by an arbitrary weight function $W_{i j}$ $[29,30]$. The weighting function reduced PSCF values when the total number of the endpoints in a cell was fewer than three times the average number of endpoints for all cells. We calculated WPSCF values to identify the possible source areas of $\mathrm{PM}_{2.5}$ in a region.

$$
W_{i j}=\left\{\begin{array}{cc}
1.00 & n_{i j}>80 \\
0.70 & 20<n_{i j} \leq 80 \\
0.42 & 10<n_{i j} \leq 20 \\
0.05 & n_{i j} \leq 10
\end{array}\right\},
$$

$\mathrm{WPSCF}_{i j}=W_{i j} \cdot \mathrm{PSCF}_{i j}$.
2.8. WCWT Analysis. The PSCF method calculates the proportion of pollution trajectories in a grid, reflecting the potential influence of the grid on the receptor site. Whether pollutant concentrations at the monitoring site are only slightly higher or much higher than the criterion, grid cells have the same PSCF value and it can be difficult to distinguish moderate pollution sources from major sources. In the Concentration-Weighted Trajectory (CWT) method [31], each grid cell is assigned a weighted concentration by averaging the sample concentrations that have associated trajectories crossing that grid cell as follows:

$$
C_{i j}=\frac{1}{\sum_{l=1}^{M} \tau_{i j l}} \sum_{l=1}^{M} c_{l} \tau_{i j l},
$$

where $C_{i j}$ is the average weighted concentration in the $i j^{\text {th }}$ cell, $l$ is the index of the trajectory, $M$ is the total number of trajectories, $C_{l}$ is the concentration observed on the arrival of trajectory $l$, and $\tau_{i j l}$ is the time spent in the $i j^{\text {th }}$ cell by trajectory $l$. The influence coefficient $W_{i j}$ is also used in the WCWT method $\left(\mathrm{WCWT}_{i j}=C_{i j} \times W_{i j}\right)$.

\section{Results and Discussion}

3.1. Air Pollution Characteristics. In 30 Chinese provincial capitals during the pollution period, mean concentrations of $\mathrm{PM}_{2.5}, \mathrm{PM}_{10}, \mathrm{O}_{3}, \mathrm{CO}, \mathrm{NO}_{2}$, and $\mathrm{SO}_{2}$ were $93.7 \mu \mathrm{g} \cdot \mathrm{m}^{-3}$, 
$124.2 \mu \mathrm{g} \cdot \mathrm{m}^{-3}, \quad 31.6 \mu \mathrm{g} \cdot \mathrm{m}^{-3}, \quad 1.5 \mathrm{mg} \cdot \mathrm{m}^{-3}, \quad 61.6 \mu \mathrm{g} \cdot \mathrm{m}^{-3}$, and $27.3 \mu \mathrm{g} \cdot \mathrm{m}^{-3}$, respectively. These results can be explained by the polluted air mass in northern China and adverse weather conditions during the pollution period. Northern cities receive relatively weak effects from monsoons, slower wind speeds, and small amount of precipitation, resulting in drier air and more sandstorms, which more often occur in winter, so it is easier for pollutants to enter the air. In contrast, lower temperatures are not beneficial to pollutants diffusion, retain pollutants near the surface, and lead to high concentrations [32]. A similar phenomenon was observed in the previous study [33]. Table 2 shows the average concentrations of the air quality index (AQI) and variations in six major pollutants. The areas with the most severe air pollution $(\mathrm{AQI} \geq 115)$ were distributed in central, northwestern, and northeastern China. These patterns may be caused by excessive pollutant emissions from coal-fired heating, biomass burning, and industrial combustion in winter $[34,35]$. The AQI of Shijiazhuang, Jinan, Taiyuan, Zhengzhou, Xi'an, and Chengdu reached 170.5, 200.5, 116.2, 260.0, 228.8, and 117.1, respectively. And the air quality levels reached a moderate or severe pollution grade, which have significant impacts on human health.

3.2. Spatial Analysis of PM2.5. Figure 2 shows the spatial distribution of daily mass concentrations of $\mathrm{PM}_{2.5}$ during the pollution period. Elevated concentrations were mainly located in central, northwestern, and eastern China and concentrated in southern Hebei, western Shandong, southern Shanxi, northern Henan, central Shaanxi, and central Sichuan because of the high emissions from fossil fuel combustion and adverse weather conditions. Overall, $\mathrm{PM}_{2.5}$ pollution in central and eastern China is more severe than in northern China due to distinct emissions sources, weather features, and source apportionment [36]. $\mathrm{PM}_{2.5}$ pollution in Handan (Hebei Province), Zhengzhou (Henan Province), Xi'an (Shaanxi Province), Yuncheng (Shanxi Province), Chengdu (Sichuan Province), Xiangyang (Hubei Province), and Jinan (Shandong Province) was highest among major polluted cities, with daily mean $\mathrm{PM}_{2.5}$ concentrations of $212.6 \pm 95.5 \mu \mathrm{g} \cdot \mathrm{m}^{-3}$, $227.2 \pm 109.9 \mu \mathrm{g} \cdot \mathrm{m}^{-3}, 186.7 \pm 59.0 \mu \mathrm{g} \cdot \mathrm{m}^{-3}, 207.8 \pm 83.1 \mu \mathrm{g} \cdot \mathrm{m}^{-3}$, $111.4 \pm 45.4 \mu \mathrm{g} \cdot \mathrm{m}^{-3}, \quad 219.3 \pm 87.8 \mu \mathrm{g} \cdot \mathrm{m}^{-3}, \quad$ and $163.5 \pm 64.7$ $\mu \mathrm{g} \cdot \mathrm{m}^{-3}$, respectively.

3.3. Daily Mean $P M_{2.5}$ Concentrations. Daily mean $\mathrm{PM}_{2.5}$ concentrations in the seven major polluted cities in Figure 3(b) exceeded the Class II category of the NAAQS. Hourly data were used to examine daily variability in $\mathrm{PM}_{2.5}$ and identify potential emission sources [37]. Trends in hourly mean $\mathrm{PM}_{2.5}$ concentrations in polluted cities were similar and exhibited multiple U-shaped curves, with higher values in the early morning (0:00-05:00) and at night (19: 00-23:00) and lower values during the middle of the day (12: 00-15:00). Such daily patterns can be explained by enhanced emissions from heating, unfavorable meteorological conditions, and variations in topography.

A comparative study of seven major cities found that the $\mathrm{PM}_{2.5}$ hourly concentrations showed a steady trend from day to night in Xi' an and Chengdu, which can be explained by the static stability of the atmosphere [38]. During the pollution episode, the mean wind speed was 1.65 and $1.62 \mathrm{~m} \cdot \mathrm{s}^{-1}$ in Xi' an and Chengdu, respectively, illustrating that the weak wind was conducive to the diffusion of pollutants. The temperature was $2.2^{\circ} \mathrm{C}$ and $9.3^{\circ} \mathrm{C}$ in $\mathrm{Xi}$ 'an and Chengdu, respectively, and relative humidity was $61 \%$ and $87 \%$, respectively. Thus, low temperature, low wind speed, and high relative humidity may have led to the accumulation of $\mathrm{PM}_{2.5}$ in winter.

High concentrations of $\mathrm{PM}_{2.5}$ appeared at midday (12: 00-13:00) in Handan and Yuncheng (Figure 3(a)), which can be explained by high emissions from coal heating, cooking, and transportation $[4,37,39]$. The lowest $\mathrm{PM}_{2.5}$ concentrations were observed in the afternoon, when the boundary layer becomes larger and the wind speed increased. After 17 : $00, \mathrm{PM}_{2.5}$ concentrations started to increase in Handan, Zhengzhou, Xi'an, Yuncheng, and Xiangyang because of decreasing wind speed and increasing vehicle emissions. $\mathrm{PM}_{2.5}$ pollution emitted from diesel truck traffic, which is allowed only during nighttime, additionally increased $\mathrm{PM}_{2.5}$ burden because the emission factors of heavy-duty vehicles are six times higher than those from light-duty vehicles [40].

3.4. Correlations between $P M_{2.5}$ and Other Gaseous Pollutants. The Pearson correlation coefficient $(r)$ was used to investigate the relationship between $\mathrm{PM}_{2.5}$ and $\mathrm{PM}_{10}, \mathrm{CO}, \mathrm{NO}_{2}$, $\mathrm{O}_{3}$, and $\mathrm{SO}_{2}$ using hourly data (Table 3 ). The analysis results showed a strong positive correlation $(r>0.9)$ between $\mathrm{PM}_{2.5}$ and $\mathrm{PM}_{10}$ in the seven polluted cities, indicating that a significant fraction of the $\mathrm{PM}_{2.5}$ was secondary $\mathrm{PM}$, such as ammonium sulfate, secondary organic aerosol, or fugitive dust, which typically have broader regional distributions than anthropogenic primary pollutants [39]. We found large values of the ratio of $\mathrm{PM}_{2.5}$ to $\mathrm{PM}_{10}$ in Handan (0.67), Zhengzhou (0.79), Xi'an (0.70), Yuncheng (0.65), Chengdu (0.68), Xiangyang (0.87), and Jinan (0.64), which indicates the large contribution of secondary aerosols to $\mathrm{PM}_{2.5}$ concentration in these regions. The ratio of $\mathrm{PM}_{2.5}$ to $\mathrm{PM}_{10}$ also shows that $\mathrm{PM}_{2.5}$ is the main component of $\mathrm{PM}_{10}$. Similar results were reported in the previous study [41]. A positive correlation between $\mathrm{PM}_{2.5}$ and $\mathrm{CO}$ was observed $(r>0.6)$, which revealed that the $\mathrm{CO}$ emission process is accompanied by the emission of fine particles.

The correlation coefficients between $\mathrm{PM}_{2.5}$ and $\mathrm{NO}_{2}$ and $\mathrm{SO}_{2}$ in Handan were very high $\left(\mathrm{PM}_{2.5}\right.$ and $\mathrm{NO}_{2}: r=0.88$; $\mathrm{PM}_{2.5}$ and $\mathrm{SO}_{2}: r=0.64$ ). This may be caused by the large amount of emissions from power plants, urban dust, and the combustion of fossil fuels. In Chengdu, the correlation coefficients of $\mathrm{PM}_{2.5}$ with $\mathrm{NO}_{2}$ and $\mathrm{SO}_{2}$ were 0.55 and 0.64 , respectively, mainly due to adverse weather conditions restricting diffusion and chemical conversion of traffic pollutants. However, correlations between $\mathrm{PM}_{2.5}$ and $\mathrm{NO}_{2}$, $\mathrm{O}_{3}$, and $\mathrm{SO}_{2}$ were lower in other cities (Table 3).

To further discuss the relationship between $\mathrm{PM}_{2.5}$ and other pollutants, we investigated the impact of other pollutants on $\mathrm{PM}_{2.5}$ by using the statistical advantage of the MGWR model that each regression coefficient was based on 
TABLE 2: Average concentrations of the air quality index (AQI) and six air pollutants in 30 provincial capitals in China during the pollution period ( $\mathrm{mg} \mathrm{m}^{-3}$ for CO; $\mu \mathrm{g} \mathrm{m}^{-3}$ for other pollutants).

\begin{tabular}{|c|c|c|c|c|c|c|c|}
\hline City & AQI & $\mathrm{PM}_{2.5}$ & $\mathrm{PM}_{10}$ & $\mathrm{CO}$ & $\mathrm{NO}_{2}$ & $\mathrm{O}_{3 \_8 \mathrm{~h}}$ & $\mathrm{SO}_{2}$ \\
\hline Beijing (BJ) & 75.03 & 42.55 & 91.24 & 1.05 & 52.46 & 27.06 & 10.61 \\
\hline Chengdu (CD) & 117.11 & 89.08 & 128.19 & 1.27 & 53.27 & 27.46 & 12.10 \\
\hline Fuzhou (FZ) & 53.45 & 35.22 & 53.56 & 0.84 & 35.91 & 42.41 & 6.68 \\
\hline Guangzhou (GZ) & 133.04 & 101.02 & 96.38 & 1.43 & 102.50 & 37.38 & 16.59 \\
\hline Guiyang (GY) & 67.83 & 48.00 & 68.60 & 1.03 & 34.23 & 30.58 & 24.74 \\
\hline Harbin (HB) & 99.79 & 75.54 & 72.27 & 1.17 & 46.61 & 35.21 & 45.03 \\
\hline Hangzhou (HZ) & 109.93 & 81.54 & 115.96 & 1.12 & 65.73 & 17.63 & 13.84 \\
\hline Hefei (HF) & 153.29 & 125.70 & 33.67 & 1.55 & 67.39 & 20.87 & 10.36 \\
\hline Hohhot (HT) & 86.74 & 43.81 & 119.15 & 1.64 & 51.25 & 33.20 & 38.17 \\
\hline Jinan (JN) & 200.52 & 156.94 & 241.90 & 2.04 & 80.58 & 22.21 & 43.91 \\
\hline Kunming (KM) & 59.23 & 35.50 & 63.68 & 0.97 & 35.55 & 42.88 & 17.43 \\
\hline Lhasa (LS) & 54.86 & 27.77 & 64.50 & 0.76 & 29.93 & 57.49 & 6.36 \\
\hline Lanzhou (LZ) & 99.23 & 58.35 & 140.02 & 1.92 & 62.70 & 34.48 & 41.42 \\
\hline Nanchang (NC) & 84.28 & 61.14 & 72.75 & 1.56 & 47.59 & 19.40 & 13.32 \\
\hline Nanjing (NJ) & 181.68 & 141.39 & 179.42 & 1.58 & 79.65 & 21.33 & 17.13 \\
\hline Nanning (NN) & 105.38 & 77.01 & 113.26 & 1.36 & 62.86 & 44.98 & 16.18 \\
\hline Shanghai (SH) & 101.25 & 76.28 & 42.54 & 1.02 & 71.30 & 37.25 & 13.09 \\
\hline Shenyang (SY) & 64.44 & 44.66 & 67.85 & 1.19 & 38.85 & 25.68 & 31.91 \\
\hline Shijiazhuang (SJZ) & 170.48 & 133.20 & 204.43 & 2.53 & 68.15 & 14.46 & 42.72 \\
\hline Taiyuan (TY) & 116.16 & 77.84 & 155.67 & 1.70 & 58.33 & 25.58 & 88.23 \\
\hline Tianjin (TJ) & 73.83 & 50.33 & 75.41 & 1.75 & 41.02 & 13.88 & 13.06 \\
\hline Urumqi (UQ) & 141.87 & 151.27 & 86.59 & 3.53 & 65.56 & 11.84 & 11.67 \\
\hline Wuhan (WH) & 146.77 & 128.22 & 35.61 & 1.53 & 61.39 & 17.88 & 11.03 \\
\hline $\mathrm{Xi}^{\prime}$ an $(\mathrm{XA})$ & 228.80 & 181.62 & 246.63 & 2.57 & 97.20 & 18.72 & 32.61 \\
\hline Xining (XN) & 86.74 & 52.42 & 115.64 & 2.01 & 26.05 & 35.55 & 22.19 \\
\hline Yinchuan (YC) & 57.21 & 32.64 & 75.06 & 1.36 & 19.01 & 27.94 & 29.65 \\
\hline Changchun (CC) & 78.70 & 55.12 & 69.68 & 1.09 & 42.06 & 33.31 & 45.43 \\
\hline Changsha (CS) & 130.39 & 124.42 & 24.44 & 1.29 & 49.02 & 27.88 & 14.54 \\
\hline Zhengzhou (ZZ) & 260.03 & 222.70 & 212.38 & 2.26 & 83.27 & 21.02 & 29.23 \\
\hline Chongqin (CQ) & 82.58 & 61.20 & 85.42 & 1.36 & 43.41 & 11.77 & 8.49 \\
\hline
\end{tabular}
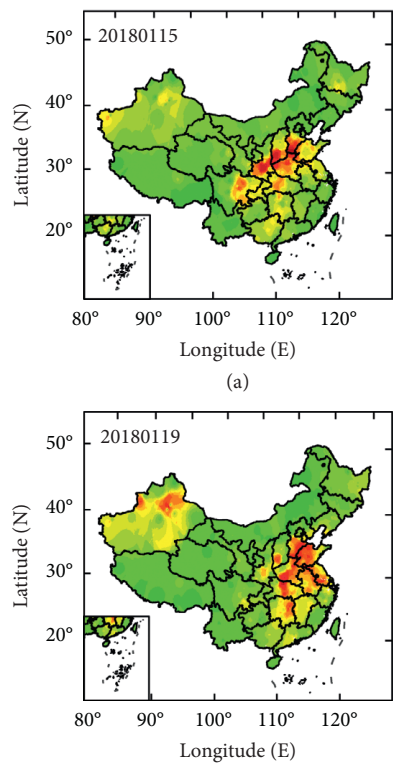

(e)

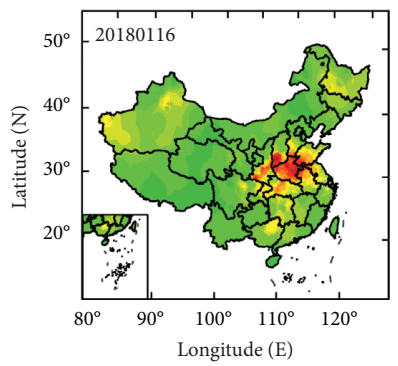

(b)

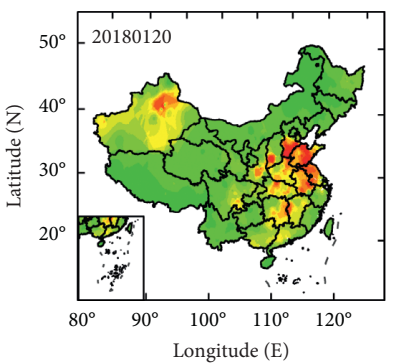

(f)

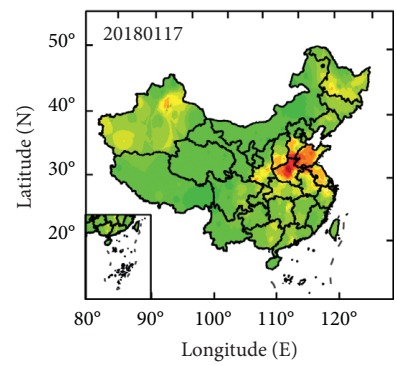

(c)

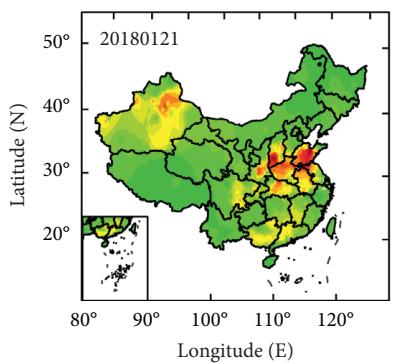

(g)

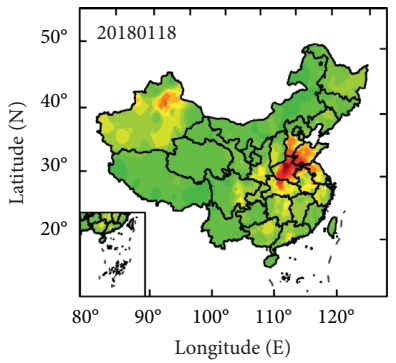

(d)

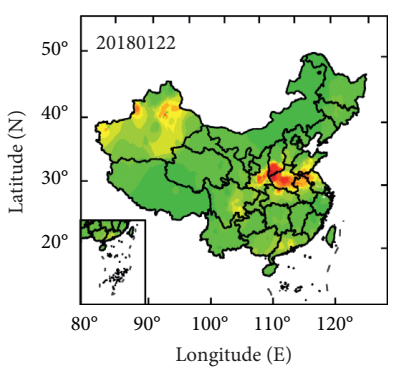

(h)

$\mathrm{PM}_{25}\left(\mu \mathrm{gm}^{-3}\right)$

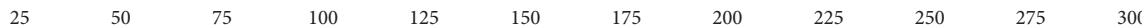

Figure 2: Spatial distribution of $\mathrm{PM}_{2.5}$ concentration $\left(\mu \mathrm{g} \mathrm{m}^{-3}\right)$ in China. 


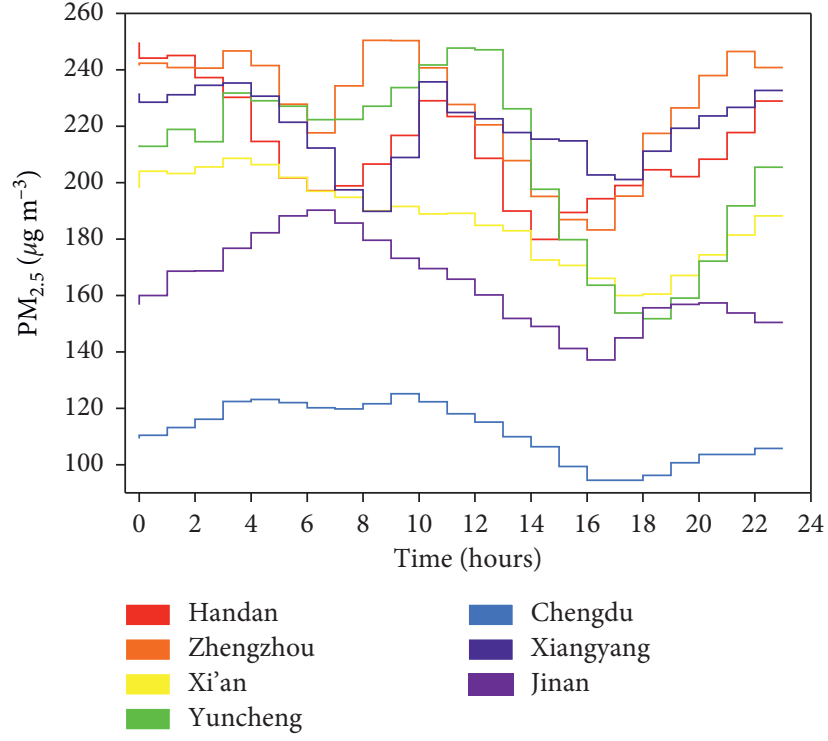

(a)

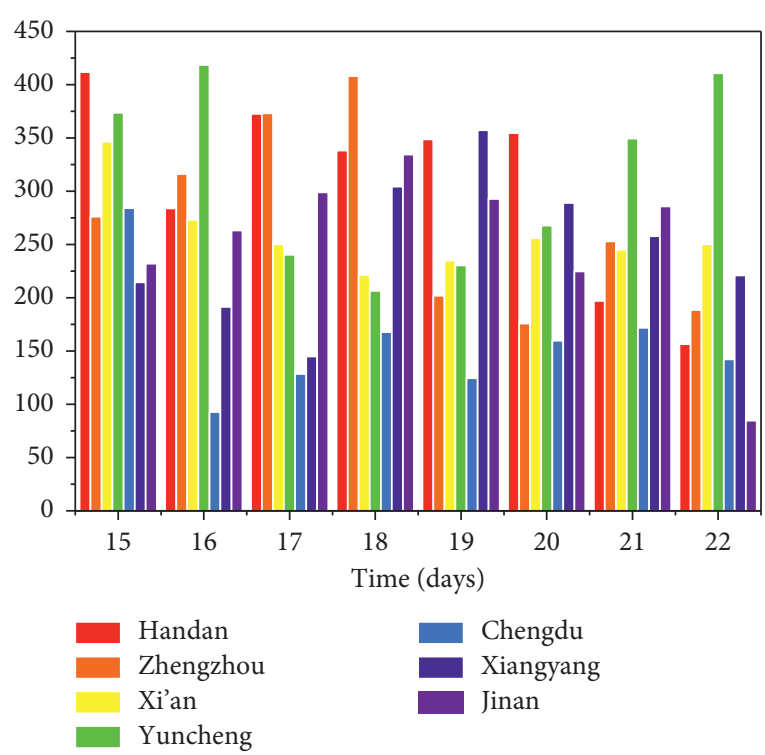

(b)

Figure 3: Hourly (a) and daily (b) mean $\mathrm{PM}_{2.5}$ concentrations in seven Chinese cities during the pollution period.

TABLe 3: Pearson correlation coefficients between $\mathrm{PM}_{2.5}, \mathrm{PM}_{10}, \mathrm{CO}, \mathrm{NO}_{2}, \mathrm{O}_{3}$, and $\mathrm{SO}_{2}$ in seven Chinese cities.

\begin{tabular}{|c|c|c|c|c|c|c|c|}
\hline & Handan & Zhengzhou & Xi'an & Yuncheng & Chengdu & Xiangyang & Jinan \\
\hline $\mathrm{PM}_{10}$ & $0.9787^{*}$ & $0.9614^{*}$ & $0.9321^{*}$ & $0.9880^{*}$ & $0.9820^{*}$ & $0.9583^{*}$ & $0.9416^{*}$ \\
\hline $\mathrm{CO}$ & $0.8277^{*}$ & $0.8594^{*}$ & 0.7593* & $0.6057^{*}$ & $0.8068^{*}$ & $0.8650^{*}$ & $0.7180^{*}$ \\
\hline $\mathrm{NO}_{2}$ & $0.8818^{*}$ & 0.4681 & 0.4562 & 0.4373 & $0.5533^{*}$ & 0.4829 & 0.4970 \\
\hline $\mathrm{O}_{3-8 \mathrm{~h}}$ & -0.0681 & -0.1522 & -0.2227 & -0.3735 & $-0.4369^{*}$ & -0.0007 & 0.0873 \\
\hline $\mathrm{SO}_{2}$ & $0.6386^{*}$ & 0.0782 & 0.3807 & 0.3695 & $0.6412^{*}$ & 0.1949 & 0.3145 \\
\hline
\end{tabular}

Note. $p<0.05$.

local regression. The model regression results were shown in Tables 4 and 5. In terms of the number of effective parameters, from the analysis of global regression results, the goodness of fit $\left(R^{2}\right)$ was $0.908(p<0.05)$, and the residual sum of squares (RSS) was 51.56 (Table 4). According to the local regression results, the local $R^{2}$ of all selected cities exceeds $0.80(p<0.05)$. These regression results showed that the MGWR model uses fewer parameters to get the regression results closer to the true value, which could be used to evaluate the relationship between $\mathrm{PM}_{2.5}$ and other pollutants. It can be clearly found from Table 5 that the relationship between $\mathrm{PM}_{2.5}$ concentration and other pollutants obtained by the MGWR model was similar to that obtained by the Pearson correlation coefficient. The MGWR analysis results showed a strong positive correlation (the regression coefficient $>1.0, p<0.01$ ) between $\mathrm{PM}_{2.5}$ and $\mathrm{PM}_{10}$ in the seven polluted cities. In all selected cities, except Yuncheng (regression coefficient is $-0.055, p<0.05$ ), $\mathrm{PM}_{2.5}$ had a significant positive correlation with $\mathrm{CO}$. There was a significant positive correlation between $\mathrm{PM}_{2.5}$ and $\mathrm{O}_{3}$ in Handan and Zhengzhou, which was contrary to the Pearson correlation coefficient. The main reason was that the MGWR model was more sensitive to nonlinear relationship than the Pearson correlation coefficient in the regression process. In addition, in all cities, except Jinan (the regression coefficient
TABLE 4: Global regression results of MGWR model.

\begin{tabular}{lc}
\hline Descriptive index & Value \\
\hline Residual sum of squares (RSS) & 5.156 \\
Log-likelihood & -12.673 \\
AICc & 517.92 \\
$R^{2}$ & 0.908 \\
Adjust $R^{2}$ & 0.889 \\
\hline
\end{tabular}

of $\mathrm{SO}_{2}$ is $\left.-0.380, p<0.05\right), \mathrm{PM}_{2.5}$ has a significant positive correlation with $\mathrm{NO}_{2}$ and $\mathrm{SO}_{2}$.

3.5. Meteorological Condition Analysis. The multiscale interaction of meteorological conditions affects air quality in a complex way [13]. Previous studies have shown that meteorological factors play an important role in the daily variation of pollutant concentrations [13]. The Pearson product-moment correlation coefficient between the hourly mean concentrations of major pollutants and local meteorological parameters (wind speed temperature, relative humidity, and sea-level pressure) in the seven cities is shown in Figure 4. In general, the correlation coefficients showed little difference among cities, indicative of regional pollution

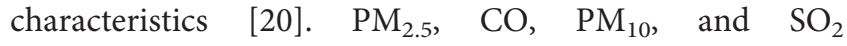


TABle 5: Statistical results of MGWR model between $\mathrm{PM}_{2.5}, \mathrm{PM}_{10}, \mathrm{CO}, \mathrm{NO}_{2}, \mathrm{O}_{3}$, and $\mathrm{SO}_{2}$ in seven Chinese cities.

\begin{tabular}{lccccccc}
\hline & Handan (0.881) & Zhengzhou (0.880) & Xi'an (0.894) & Yuncheng (0.877) & Chengdu (0.932) & Xiangyang (0.876) & Jinan (0.822) \\
\hline $\mathrm{PM}_{10}$ & $1.050^{* *}$ & $1.080^{* *}$ & $1.197^{* *}$ & $1.169^{* *}$ & $1.159^{* *}$ & $1.198^{* *}$ & $1.029^{* *}$ \\
$\mathrm{CO}$ & 0.151 & 0.114 & $0.059^{*}$ & $-0.055^{*}$ & 0.087 & $0.077^{*}$ & 0.191 \\
$\mathrm{NO}_{2}$ & $0.142^{*}$ & $0.148^{*}$ & 0.144 & 0.124 & $0.197^{*}$ & $0.150^{*}$ & $0.146^{*}$ \\
$\mathrm{SO}_{2}$ & $0.354^{*}$ & 0.342 & 0.236 & $0.239^{*}$ & $0.326^{*}$ & 0.253 & $-0.380^{*}$ \\
$\mathrm{O}_{3-8 \mathrm{~h}}$ & 0.041 & $0.031^{*}$ & $-0.040^{*}$ & -0.010 & -0.021 & -0.024 & 0.047 \\
\hline
\end{tabular}

Note. ${ }^{*}, p<0.05 ;{ }^{* *}, p<0.01$. Numbers in parentheses represent local $R^{2}$.

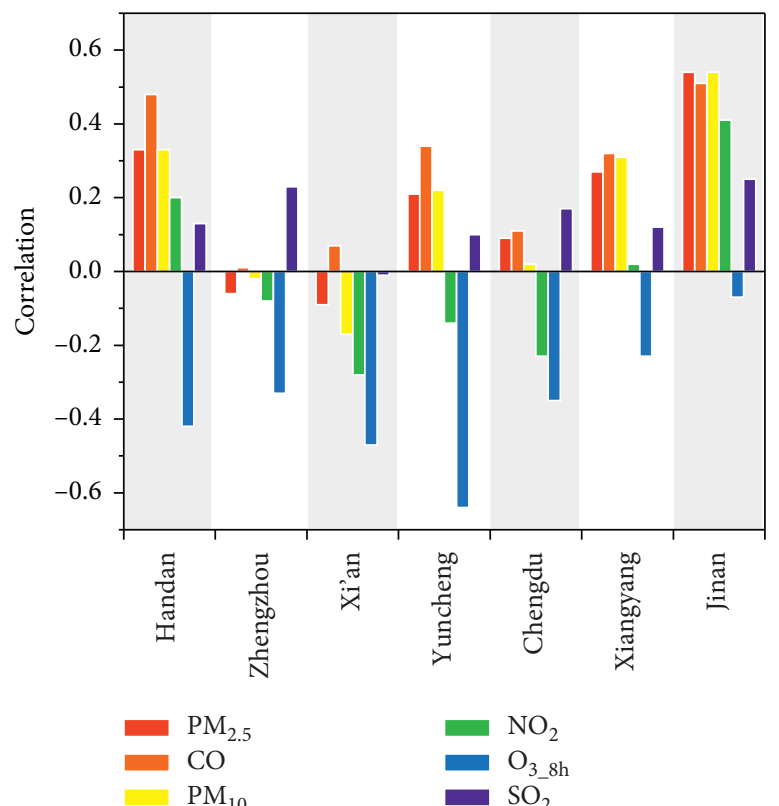

(a)

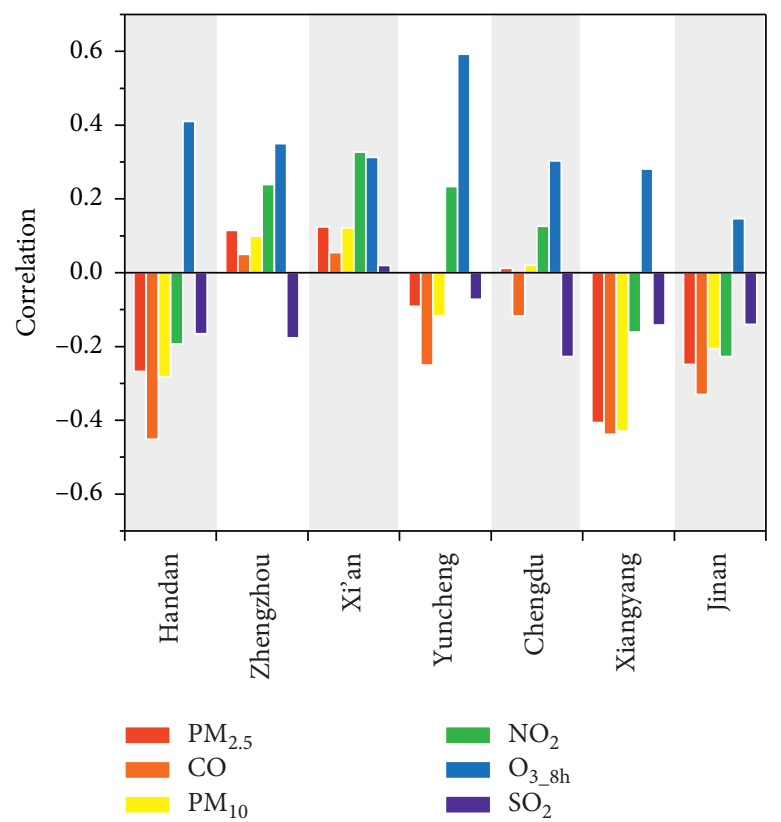

(c)

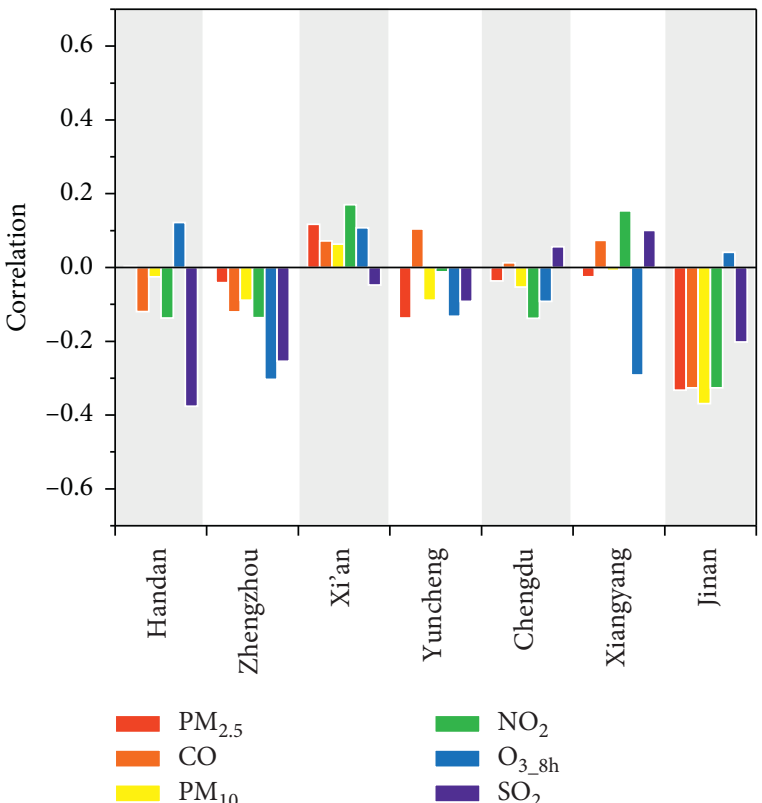

(b)

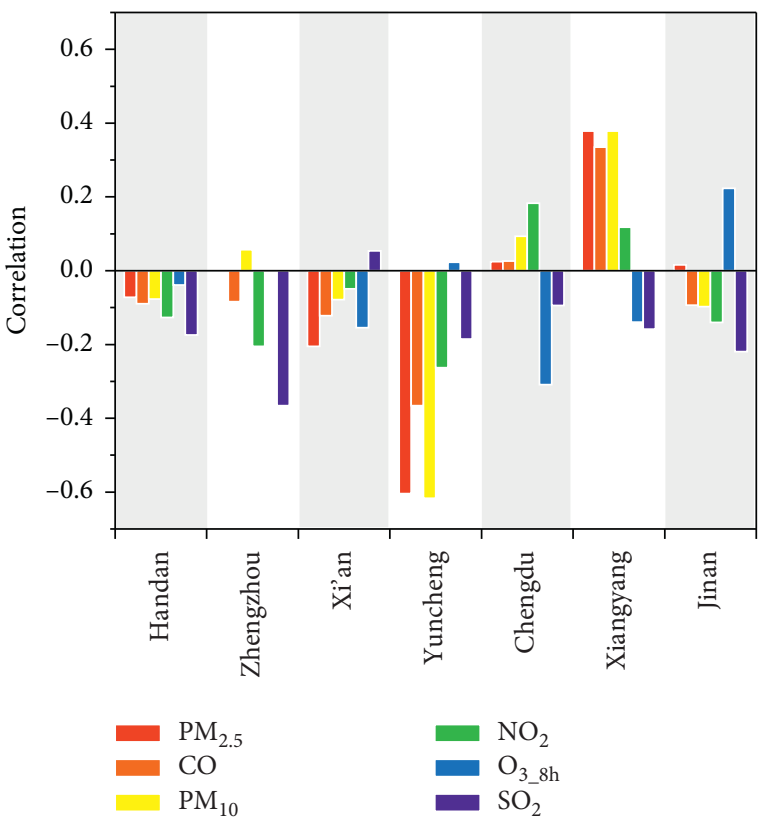

(d)

Figure 4: The correlation between pollutant concentrations and temperature (a), wind speed (b), relative humidity (c), and sea-level pressure (d). 
concentrations were positively correlated with temperature in Handan, Yuncheng, Chengdu, Xiangyang, and Jinan, while $\mathrm{O}_{3}$ concentrations were negatively correlated with temperature in all cities. This can be explained by the fact that solar radiation is the main stimulus for the chemical reactions of $\mathrm{NO}_{2}$ and $\mathrm{O}_{3}$ and temperature, which are affected by atmospheric turbulence and influence regional pollutant concentrations [3].

Generally, pollutant concentrations decrease with increasing wind speed. Deng et al. [42] and Wang et al. [43] found that low primary pollutant concentrations result in high $\mathrm{O}_{3}$ concentrations and cause a positive correlation between wind speed and $\mathrm{O}_{3}$ concentration. We found a positive correlation between $\mathrm{O}_{3}$ concentration and wind speed in Handan, Xi'an, and Jinan (Figure 4(b)). We also found a negative correlation between pollutant concentrations and wind speed in Zhengzhou and a positive correlation between $\mathrm{PM}_{2.5}, \mathrm{CO}, \mathrm{PM}_{10}, \mathrm{NO}_{2}$, and $\mathrm{O}_{3}$ with wind speed in Xi'an, possibly because strong winds can stir up dust. $\mathrm{O}_{3}$ concentration was weakly positively correlated with relative humidity in the seven cities (Figure 4(c)). Primary pollutant concentrations were negatively correlated with relative humidity in Handan, Yuncheng, Xiangyang, and Jinan and positively correlated in other cities (Figure 4(c)), which indicates that lower relative humidity is unfavorable for scrubbing gaseous pollutants. Pollutant concentrations were negatively correlated with sea-level pressure in all cities except Xiangyang, where a positive correlation was observed, possibly for two reasons. First, the atmosphere would be stable under the low air pressure, leading to the inversion layer taking place easily and the air convection slowing down, thus resulting in higher concentrations of atmospheric pollutants. The increase in air pressure may have led to the enhancement of air advection as well as an increase in wind speed, which plays a positive role in the diffusion of air pollutants.

$\mathrm{PM}_{2.5}$ concentrations in the study cities were influenced not only by local emissions but also by the surrounding pollution region. To further study the influence of wind speed and direction on pollutant diffusion, the wind rose and the distribution of hourly $\mathrm{PM}_{2.5}$ concentrations, wind speed, and wind direction in the target cities were calculated (Figures 5 and 6). During the pollution episode, the lowest wind speeds were found in Handan. And the wind speeds associated with north and northwesterly winds were low in Handan, Zhengzhou, and Yuncheng, while weak winds were associated with the south and southeasterly directions in Xi'an, Chengdu, and Xiangyang. In addition, east winds were weak in Jinan (Figure 5). As shown in Figure 6, high $\mathrm{PM}_{2.5}$ concentrations were associated with weak winds, less than $2-3 \mathrm{~m} \cdot \mathrm{s}^{-1}$. Previous studies have shown that low wind speeds can stimulate the accumulation of gaseous pollutants [44], indicative of the influence of regional transport from the surrounding polluted regions.

3.6. Statistical Analysis of Trajectory Clustering. Cluster analysis is a widely applied multivariate statistical analysis technique. According to the similarity principle of trajectory space, large numbers of backward trajectories are divided into different transport groups or clusters [45]. The calculated backward trajectories were divided into five main trajectory clusters from the total spatial variance using the HYSPLIT and TrajSat models. Main transport pathways were divided into nine categories according to the results of the trajectory clusters (Figure 7): long northwest (LNW: Handan C2, Zhengzhou C3, C4, and C5, Xi'an C2 and C3, Yuncheng C2, C3, and C4, Xiangyang C3 and C5, and Jinan $\mathrm{C} 3$ and C4), short northwest (SNW: Xi'an C4 and C5 and Jinan C1), long north (LN: Handan C3), short north (SN: Handan C4 and C5, Zhengzhou C2, Chengdu C4, and Xiangyang C4), short southwest (SSW: Handan C1, Zhengzhou C1, Xi'an C1, and Jinan C2 and C5), long southwest (LSW: Yuncheng C1 and C5 and Xiangyang C2), long west (LW: Chengdu C1 and C3), short east (SE: Chengdu C2), and short south (SS: Chengdu C5 and Xiangyang C1).

The northwestern trajectory clusters (LNW and SNW) passing through some natural sources of aerosol emissions including northern Xinjiang, southern Inner Mongolia, northwestern Gansu, and central Shannxi were predominant and accounted for dominant trajectories $72.9 \%, 55.1 \%$, $80.2 \%, 90.6 \%, 38.5 \%$, and $41.2 \%$ of clusters, respectively, in Handan, Zhengzhou, Xi'an, Yuncheng, Xiangyang, and Jinan. LW pathways made a large contribution of $53.1 \%$ in Chengdu. Particle matters accumulated more in short trajectories. As Table 6 shows, the highest mean $\mathrm{PM}_{2.5}$ concentrations were associated with SSW (Handan C1, Xi'an C1, and Jinan C2 and C5), SN (Zhengzhou C2 and Xiangyang C4), LSW (Yuncheng C1 and C5), and SS (Chengdu C5) pathways. Our results are consistent with those from a study from Perrone et al. [46], which found that a longer airflow trajectory had a faster speed not conducive to particle deposition according to the principle of dynamics.

3.7. Source Analysis. Figures 8 and 9 show the $72 \mathrm{~h}$ backward trajectories and potential sources of $\mathrm{PM}_{2.5}$ with WPSCF and WCWT. The warm-colored areas of the map represent the main potential sources of pollution that had a significant effect on $\mathrm{PM}_{2.5}$ concentration. The cold-colored regions represent minor potential sources of pollution. Figures 8 and 9 show areas with WPSCF $>0.5$ and WCWT $>100 \mu \mathrm{g} \cdot \mathrm{m}^{-3}$ (i.e., where main potential sources were concentrated). $\mathrm{PM}_{2.5}$ pollution in these regions was mainly caused by artificial emissions. In areas with WPSCF $<0.5$ and WCWT $<100 \mu \mathrm{g} \cdot \mathrm{m}^{-3}$ (i.e., secondary potential sources), $\mathrm{PM}_{2.5}$ pollution was related to the presence of arid and semiarid areas and desert areas, such as the Badain Jaran Desert, the Ulan Buh Desert, the Kubuqi Desert, and the Tengger Desert in Inner Mongolia, where dust storms occur frequently $[47,48]$.

The identity and distribution of the main potential sources of $\mathrm{PM}_{2.5}$ in each polluted city differed. Our results suggest that regional transport from the northwest and south of Handan plays a dominant role in the formation of pollution events. Pollution sources were mainly distributed in southern Hebei, south of Shanxi, and north of Shaanxi, 


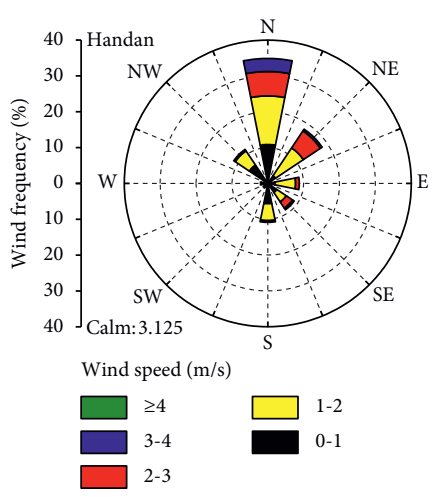

(a)

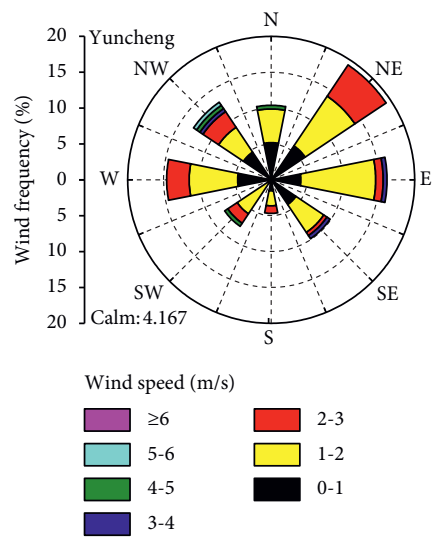

(d)

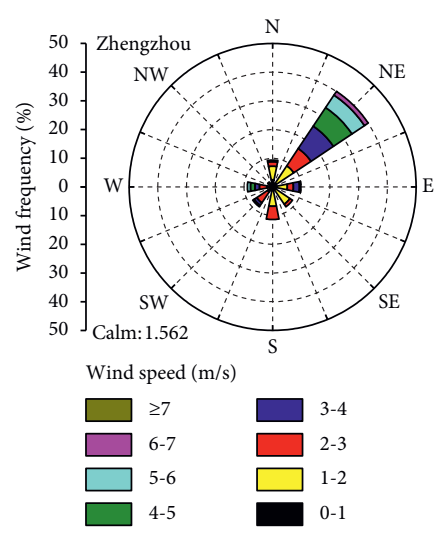

(b)

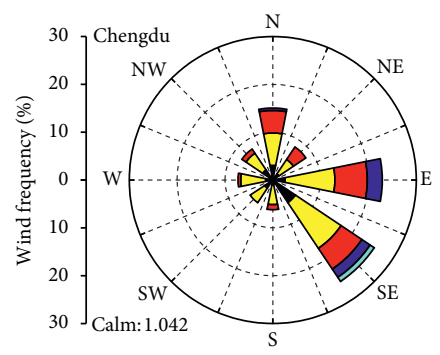

Wind speed $(\mathrm{m} / \mathrm{s})$

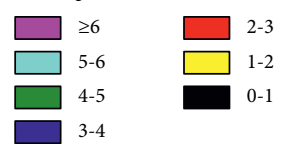

(e)

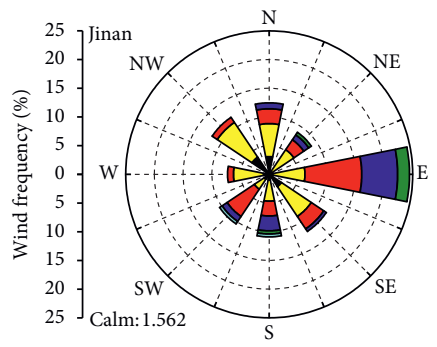

Wind speed $(\mathrm{m} / \mathrm{s})$

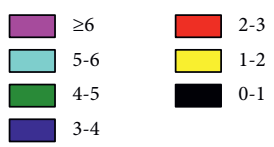

(g)

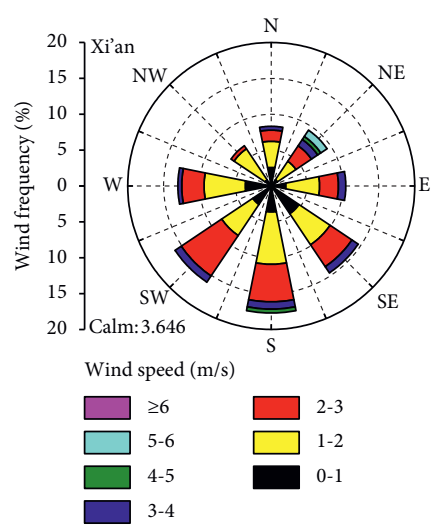

(c)
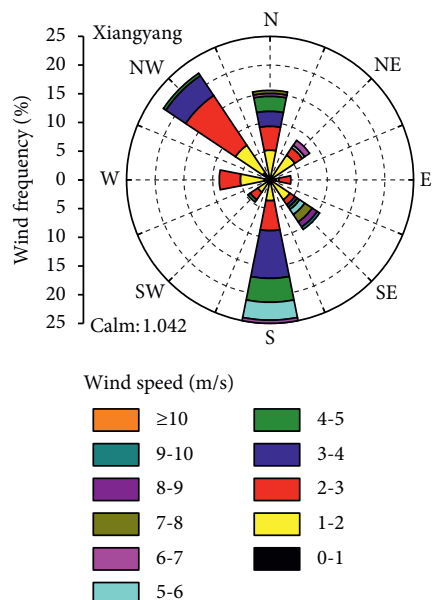

(f)

Figure 5: Wind rose plots for seven Chinese cities. Calms represent wind speeds $<1 \mathrm{~m} \cdot \mathrm{s}^{-1}$.

which are the main coal-burning areas in winter. These anthropogenic emissions were transported to Handan through low-level air mass. In addition, Handan is a developed industrial city with many power plants and energyconsuming factories producing a large amount of industrial emissions. For Zhengzhou, high WPSCF and WCWT values were concentrated in northern Shaanxi and southern Shanxi because of Zhengzhou's large population density and high energy consumption, which depend heavily on fossil fuels. The high potential source regions for Xi'an were mainly 


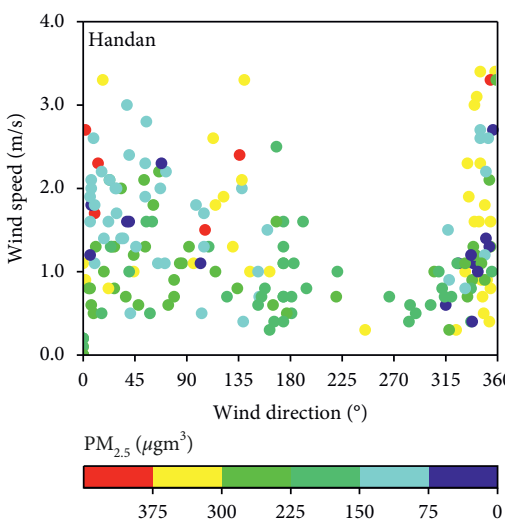

(a)

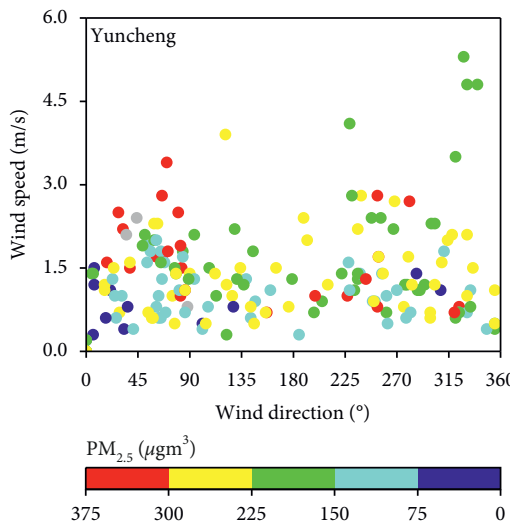

(d)

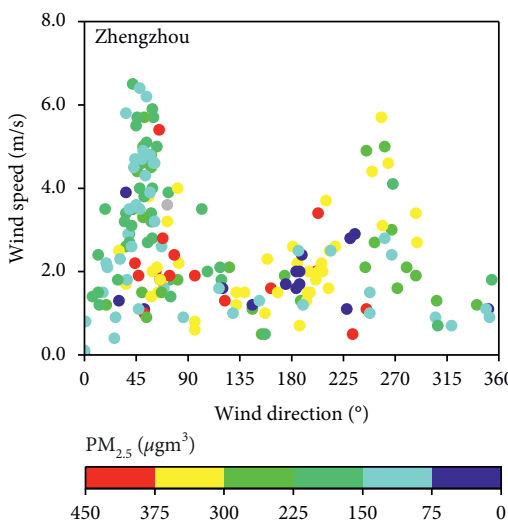

(b)

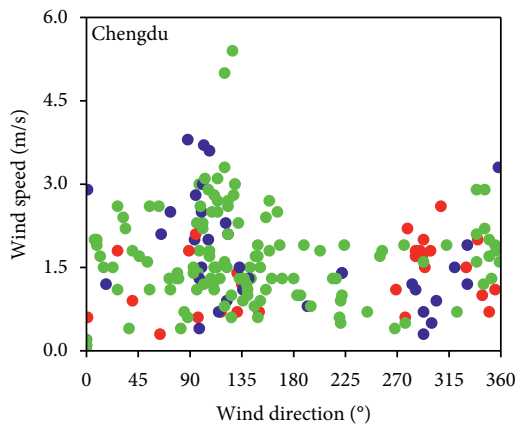

$\mathrm{PM}_{25}\left(\mu \mathrm{gm}^{3}\right)$

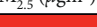

150

(e)

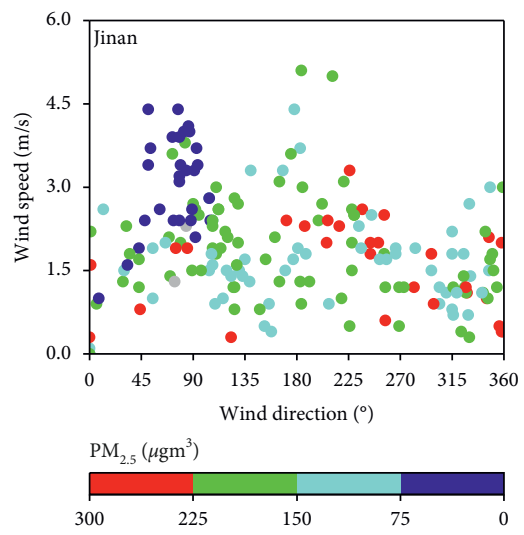

(g)

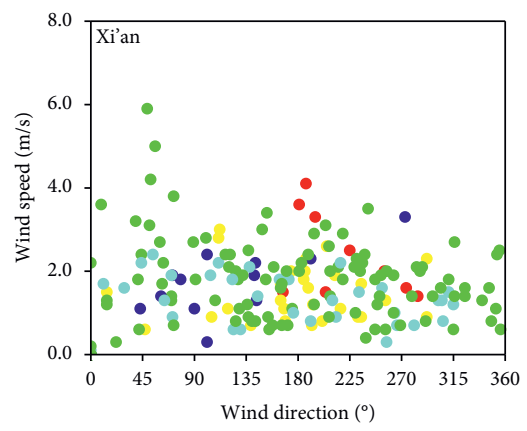

$\mathrm{PM}_{2.5}\left(\mu \mathrm{gm}^{3}\right)$

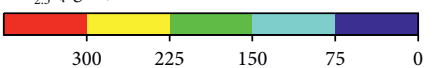

(c)

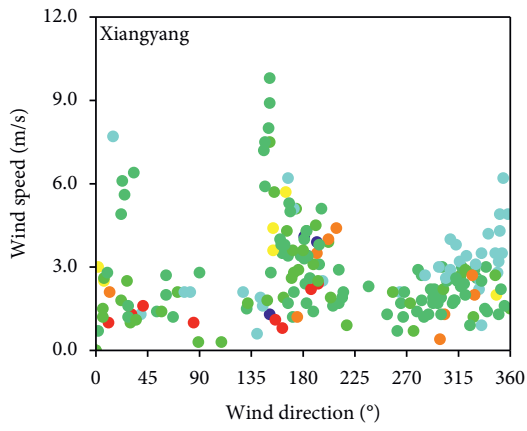

$\mathrm{PM}_{2.5}\left(\mu \mathrm{gm}^{3}\right)$

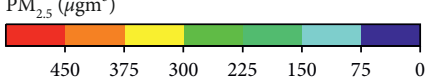

(f)

Figure 6: Distribution of $\mathrm{PM}_{2.5}$ concentrations with observed hourly wind direction and speed in each direction in seven Chinese cities.

distributed around Xi'an and were caused by motor vehicle emissions, thermal power plants, and coal burning for heating in winter. Ningxia and Gansu may also be important potential sources of $\mathrm{PM}_{2.5}$ pollution in Xi'an since these areas are the main sources of dust in winter. Central Gansu, Ningxia, and Shaanxi were the main potential sources of pollution in Yuncheng. The high potential source regions for
Chengdu were located in surrounding areas due to unfavorable meteorological conditions in winter. High WPSCF and WCWT values were mainly concentrated in the south of Henan where population density and biomass burning are high. The high potential source regions for Jinan were distributed in southwestern Shandong, northeastern Henan, east of Shandong, and south of Hebei [50]. 


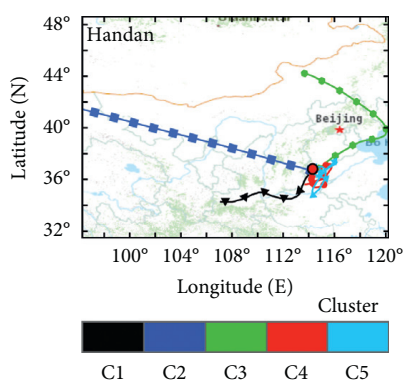

(a)

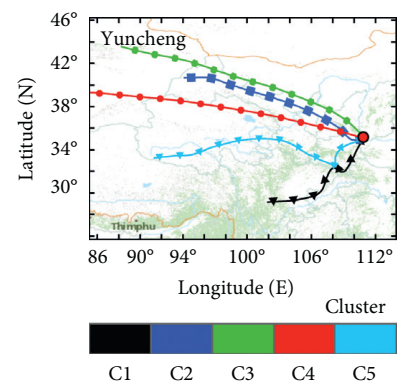

(d)

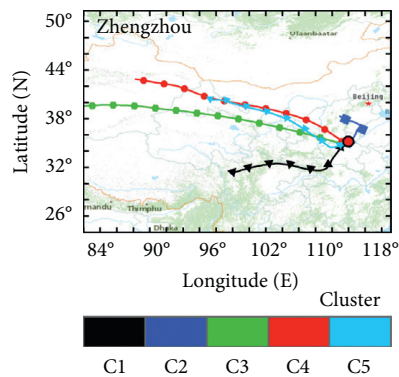

(b)

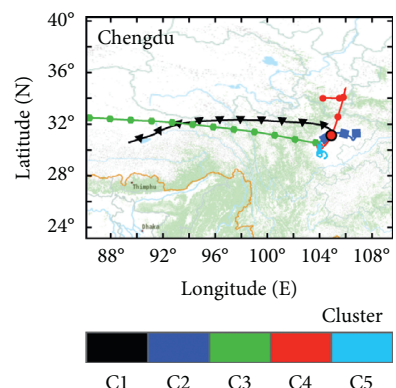

(e)

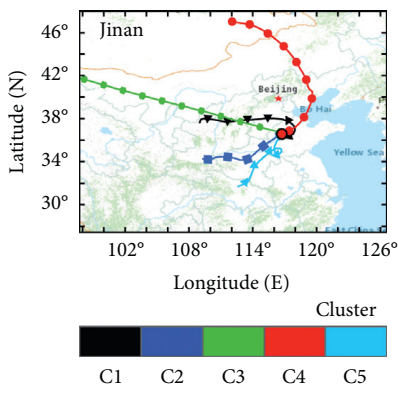

(g)

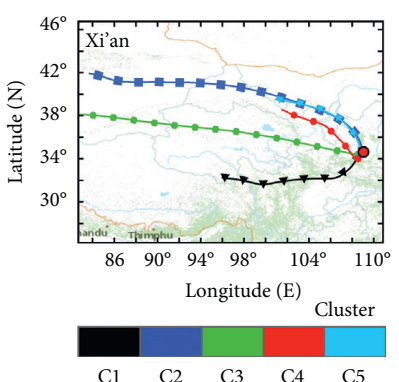

(c)

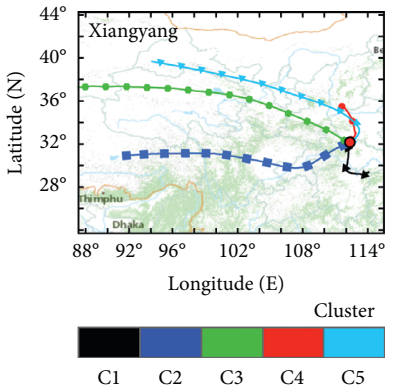

(f)

FIgURE 7: Spatial distribution of cluster means in seven Chinese cities, with the large red dots representing cities.

TABLE 6: Mean backward trajectory clusters frequency (\%) and $\mathrm{PM}_{2.5}$ mean concentrations $\left(\mu \mathrm{g} \mathrm{m}^{-3}\right)$ associated with the five trajectory clusters in seven Chinese cities. Bold numbers represent the mean $\mathrm{PM}_{2.5}$ concentration of each trajectory cluster.

\begin{tabular}{|c|c|c|c|c|c|}
\hline City & Cluster1 (C1) & Cluster2 (C2) & Cluster3 (C3) & Cluster4 (C4) & Cluster5 (C5) \\
\hline \multirow{2}{*}{ Handan } & 12.50 & 72.92 & 8.33 & 4.17 & 2.08 \\
\hline & 304.00 & 207.99 & 109.92 & 227.69 & 211.25 \\
\hline \multirow{2}{*}{ Zhengzhou } & 10.42 & 12.50 & 38.54 & 21.88 & 16.67 \\
\hline & 255.14 & 270.89 & 208.07 & 330.65 & 205.90 \\
\hline \multirow{2}{*}{ Xi'an } & 19.79 & 12.50 & 35.42 & 15.63 & 16.67 \\
\hline & 200.36 & 182.73 & 192.90 & 198.91 & 164.13 \\
\hline \multirow{2}{*}{ Yuncheng } & 5.21 & 17.71 & 35.42 & 37.50 & 4.17 \\
\hline & 235.56 & 233.98 & 191.93 & 200.75 & 228.65 \\
\hline \multirow{2}{*}{ Chengdu } & 11.46 & 32.29 & 41.67 & 7.29 & 7.29 \\
\hline & 112.90 & 119.31 & 120.79 & 98.50 & 135.93 \\
\hline \multirow{2}{*}{ Xiangyang } & 8.33 & 34.38 & 23.96 & 18.75 & 14.58 \\
\hline & 198.17 & 208.89 & 192.95 & 261.73 & 261.04 \\
\hline \multirow{2}{*}{ Jinan } & 6.25 & 14.58 & 62.50 & 7.29 & 9.38 \\
\hline & 162.11 & 183.07 & 189.33 & 143.35 & 191.00 \\
\hline
\end{tabular}




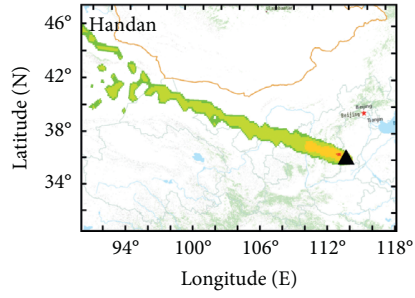

(a)

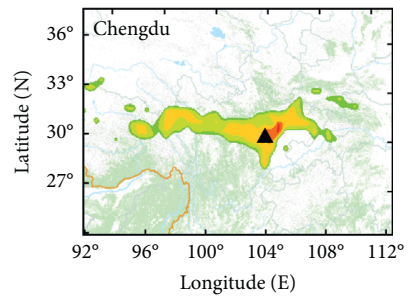

(e)

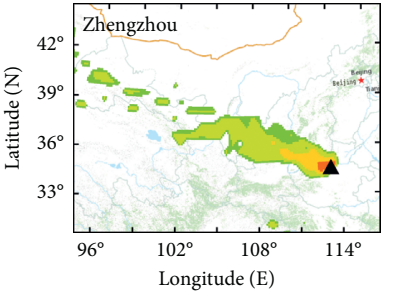

(b)

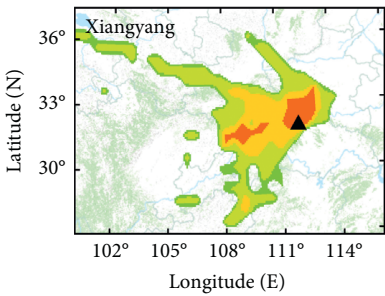

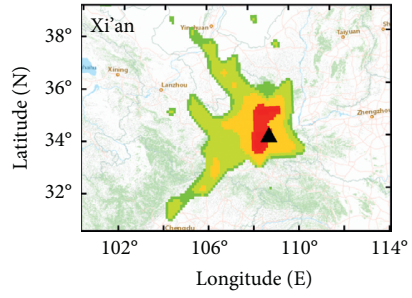

(c)

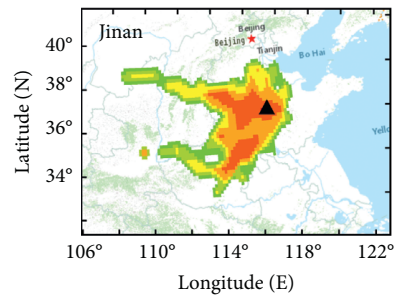

(g)

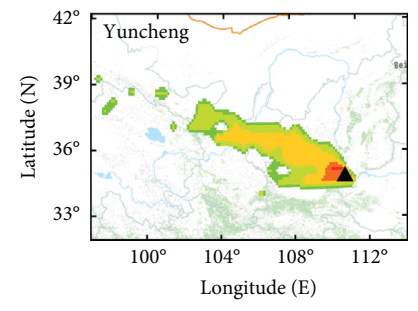

(d)

0.3

0.4

0.5

0.6

0.7

0.8

FIgURE 8: Potential sources of $\mathrm{PM}_{2.5}$ in seven Chinese cities according to the Weight Potential Source Contribution Function (WPSCF), with the large black triangles representing cities.

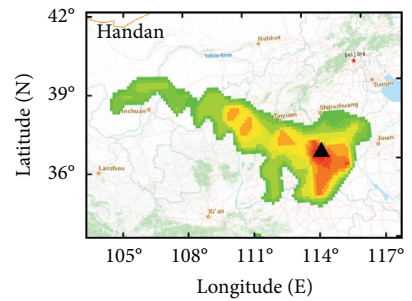

(a)

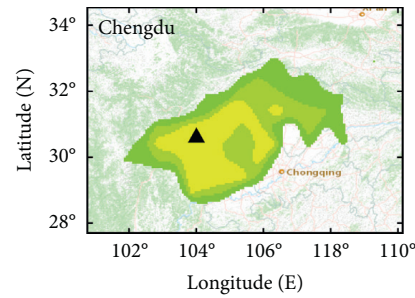

(e)

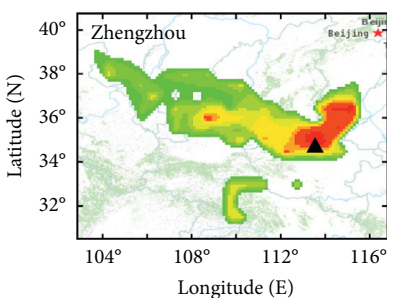

(b)

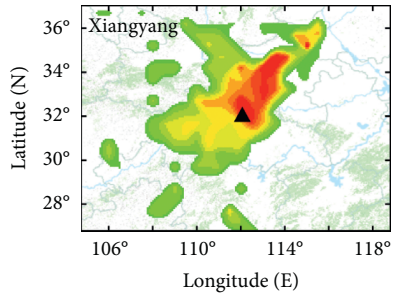

(f)

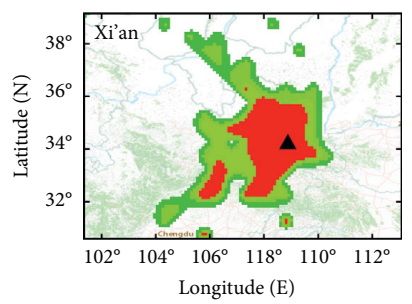

(c)

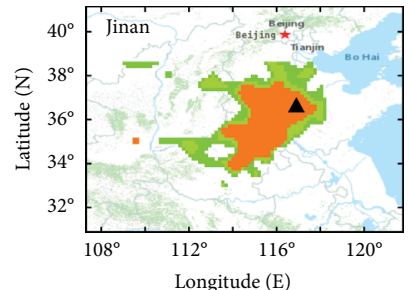

$(\mathrm{g})$

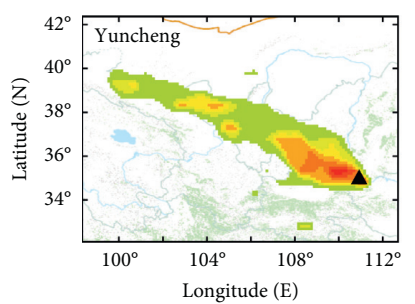

(d)

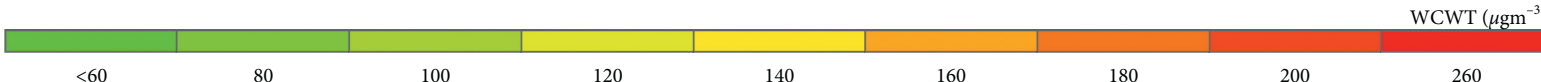

Figure 9: Potential sources of $\mathrm{PM}_{2.5}$ by Concentration-Weighted Trajectory (CWT) in seven Chinese cities, with the large black triangles representing cities.

\section{Conclusions}

Air pollution is a serious environmental and societal problem in China. This study mainly analyzed the characteristics of a severe air pollution incident that occurred from January 15 to January 22, 2018, in seven major polluted cities in China. We also analyzed the effects of meteorological conditions and identified potential pollution sources. This study provides an important scientific basis for the design of pollution control strategies in this region.

The most serious air pollution was observed in Handan, Zhengzhou, Xi'an, Yuncheng, Chengdu, Xiangyang, and
Jinan, where mean $\mathrm{PM}_{2.5}$ concentrations were $212.6 \mu \mathrm{g} \cdot \mathrm{m}^{-3}$, $227.2 \mu \mathrm{g} \cdot \mathrm{m}^{-3}, \quad 186.7 \mu \mathrm{g} \cdot \mathrm{m}^{-3}, \quad 207.8 \mu \mathrm{g} \cdot \mathrm{m}^{-3}, \quad 111.4 \mu \mathrm{g} \cdot \mathrm{m}^{-3}$, $219.3 \mu \mathrm{g} \cdot \mathrm{m}^{-3}$, and $163.5 \mu \mathrm{g} \mathrm{m}^{-3}$, respectively. Hourly variation in mean $\mathrm{PM}_{2.5}$ concentration showed a multiple $\mathrm{U}$-shaped trend with higher values at night and lower values during the day. The ratio of $\mathrm{PM}_{2.5}$ to $\mathrm{PM}_{10}$ was large in all cities, indicating the large contribution of secondary aerosols to $\mathrm{PM}_{2.5}$ concentrations in these regions. $\mathrm{PM}_{2.5}$ concentrations showed positive correlations with $\mathrm{PM}_{10}, \mathrm{CO}, \mathrm{NO}_{2}$, and $\mathrm{SO}_{2}$ and negative correlations with $\mathrm{O}_{3}$.

Pollutant concentrations were generally negatively correlated with sea-level pressure and wind speed in 
Handan, Xi'an, Zhengzhou, and Yuncheng and $\mathrm{PM}_{2.5}, \mathrm{PM}_{10}$, $\mathrm{CO}$, and $\mathrm{SO}_{2}$ concentrations were positively correlated with temperature, while the opposite occurred for $\mathrm{NO}_{2}$ and $\mathrm{O}_{3}$ concentrations in Handan, Xi'an, Zhengzhou, Yuncheng, and Jinan. Correlations with relative humidity showed significant regional differences. $\mathrm{PM}_{2.5}, \mathrm{PM}_{10}, \mathrm{CO}$, and $\mathrm{SO}_{2}$ were negatively correlated with relative humidity in Handan, Yuncheng, Chengdu, and Jinan, while $\mathrm{NO}_{2}$ and $\mathrm{O}_{3}$ were negatively correlated with wind speed. We identified calm meteorological conditions as one of the main factors causing the haze event.

The analysis of transport contributions indicated that the northwestern trajectory yielded the greatest $\mathrm{PM}_{2.5}$ contributions, ranging between $41.2 \%$ and $90.6 \%$ in target cities, whereas the highest mean $\mathrm{PM}_{2.5}$ concentrations were generally associated with SSW, SN, LSW, and SS pathways. The potential pollution sources calculated by WPSCF and WCWT models were very similar and the highest values of WPSCF $(>0.5)$ and WCWT $\left(>100 \mu \mathrm{g} \cdot \mathrm{m}^{-3}\right)$ were distributed in densely populated and industrial areas.

\section{Data Availability}

Data used in this paper can be obtained from Chao $\mathrm{He}$ (he_chao@whu.edu.cn) upon request.

\section{Conflicts of Interest}

The authors declare that they have no conflicts of interest.

\section{Acknowledgments}

This research was supported by funding from the China Scholarship Council (Grant no. 201506270052), Shenzhen Basic Research Project, China (Grant no. JCYJ20150630153917252), and Collaborative Innovation Center of Geospatial Technology in Wuhan University. The authors gratefully acknowledge the National Urban Air Quality Real-Time Publishing Platform for help with daily mean PM10 concentrations data and the NOAA Air Resources Laboratory (ARL) for the provision of the HYSPLIT model used in this publication.

\section{References}

[1] M. O. Andreae, O. Schmid, H. Yang et al., "Optical properties and chemical composition of the atmospheric aerosol in urban Guangzhou, China," Atmospheric Environment, vol. 42, no. 25, pp. 6335-6350, 2008.

[2] J. J. Cao, S. C. Lee, K. F. Ho et al., "Spatial and seasonal variations of atmospheric organic carbon and elemental carbon in Pearl River Delta Region, China," Atmospheric Environment, vol. 38, no. 27, pp. 4447-4456, 2004.

[3] J. He, S. Gong, Y. Yu et al., "Air pollution characteristics and their relation to meteorological conditions during 2014-2015 in major Chinese cities," Environmental Pollution, vol. 223, pp. 484-496, 2017.

[4] Y. Chen, A. Ebenstein, M. Greenstone, and H. Li, "Evidence on the impact of sustained exposure to air pollution on life expectancy from China's Huai River policy," Proceedings of the National Academy of Sciences, vol. 110, no. 32, pp. 12936-12941, 2013.

[5] S. Menon, J. Hansen, L. Nazarenko, and Y. F. Luo, "Climate effects of black carbon aerosols in China and India," Science, vol. 297 , no. 5590, pp. 2250-2253, 2002.

[6] C. Zhang, L. Litao Wang, M. Qi et al., "Evolution of key chemical components in $\mathrm{PM}_{2.5}$ and potential formation mechanisms of serious haze events in handan, China," Aerosol and Air Quality Research, vol. 18, no. 7, pp. 1545-1557, 2018.

[7] N. Jiang, S. Yin, Y. Guo et al., "Characteristics of mass concentration, chemical composition, source apportionment of $\mathrm{PM}_{2.5}$ and $\mathrm{PM}_{10}$ and health risk assessment in the emerging megacity in China," Atmospheric Pollution Research, vol. 9, no. 2, pp. 309-321, 2018.

[8] X. Niu, J. Cao, Z. Shen et al., " $\mathrm{PM}_{2.5}$ from the Guanzhong Plain: chemical composition and implications for emission reductions," Atmospheric Environment, vol. 147, pp. 458-469, 2016.

[9] M. Crippa, F. Canonaco, J. G. Slowik et al., "Primary and secondary organic aerosol origin by combined gas-particle phase source apportionment," Atmospheric Chemistry and Physics, vol. 13, no. 16, pp. 8411-8426, 2013.

[10] Y. Gao, X. Liu, C. Zhao, and M. Zhang, "Emission controls versus meteorological conditions in determining aerosol concentrations in Beijing during the 2008 Olympic Games," Atmospheric Chemistry and Physics, vol. 11, no. 23, pp. 12437-12451, 2011.

[11] J. He, Y. Yu, N. Liu, and S. Zhao, "Numerical model-based relationship between meteorological conditions and air quality and its implication for urban air quality management," International Journal of Environment and Pollution, vol. 53, no. 3/4, pp. 265-286, 2013.

[12] C. He, S. Hong, L. Zhang et al., "Global, continental, and national variation in $\mathrm{PM}_{2.5}, \mathrm{O}_{3}$, and $\mathrm{NO}_{2}$ concentrations during the early 2020 COVID-19 lockdown," Atmospheric Pollution Research, vol. 12, no. 3, pp. 136-145, 2021.

[13] J. J. He, Y. Yu, Y. C. Xie et al., "Numerical model based artificial neural network model and its application for quantifying impact factors of urban air quality," Water, Air, \& Soil Pollution, vol. 222, pp. 227-235, 2016.

[14] Y. Huang, Q. Yan, and C. Zhang, "Spatial-temporal distribution characteristics of $\mathrm{PM}_{2.5}$ in China in 2016," Journal of Geovisualization and Spatial Analysis, vol. 2, no. 2, p. 12, 2018.

[15] C.-H. Huang and C.-Y. Tai, "Relative humidity effect on $\mathrm{PM}_{2.5}$ readings recorded by collocated beta attenuation monitors," Environmental Engineering Science, vol. 25, no. 7, pp. 10791090, 2008.

[16] R. Zalakeviciute, J. López-Villada, and Y. Rybarczyk, "Contrasted effects of relative humidity and precipitation on urban $\mathrm{PM}_{2.5}$ pollution in high elevation urban areas," Sustainability, vol. 10, no. 6, p. 2064, 2018.

[17] K. Biswas, A. Chatterjee, and J. Chakraborty, "Comparison of air pollutants between Kolkata and siliguri, India, and its relationship to temperature change," Journal of Geovisualization and Spatial Analysis, vol. 4, no. 2, p. 25, 2020.

[18] Y. Q. Wang, "MeteoInfo: GIS software for meteorological data visualization and analysis," Meteorological Applications, vol. 21, no. 2, pp. 360-368, 2014.

[19] C. Cao, S. Zheng, and R. P. Singh, "Characteristics of aerosol optical properties and meteorological parameters during three major dust events (2005-2010) over Beijing, China," Atmospheric Research, vol. 150, pp. 129-142, 2014.

[20] G. Wang, S. Cheng, J. Lang et al., "Characteristics of $\mathrm{PM}_{2.5}$ and assessing effects of emission-reduction measures in the heavy 
polluted city of Shijiazhuang, before, during, and after the ceremonial parade 2015," Aerosol and Air Quality Research, vol. 17, no. 2, pp. 499-512, 2017.

[21] F. Zemmer, F. Karaca, and F. Ozkaragoz, "Ragweed pollen observed in Turkey: detection of sources using back trajectory models," Science of the Total Environment, vol. 430, pp. 101108, 2012.

[22] M. Filonchyk and H. Yan, "The characteristics of air pollutants during different seasons in the urban area of Lanzhou, Northwest China," Environmental Earth Sciences, vol. 77, no. 22, p. 763, 2018.

[23] L. T. Wang, Z. Wei, J. Yang et al., “The 2013 severe haze over southern Hebei, China: model evaluation, source apportionment, and policy implications," Atmospheric Chemistry and Physics, vol. 14, no. 6, pp. 3151-3173, 2014.

[24] A. S. Fotheringham, W. Yang, and W. Kang, "Multiscale geographically weighted regression (MGWR)," Annals of the American Association of Geographers, vol. 107, no. 6, pp. 1247-1265, 2017.

[25] C. Wu, F. Ren, W. Hu, and Q. Du, "Multiscale geographically and temporally weighted regression: exploring the spatiotemporal determinants of housing prices," International Journal of Geographical Information Science, vol. 33, no. 3, pp. 1-23, 2018.

[26] Y. Q. Wang, X. Y. Zhang, and R. R. Draxler, “TrajStat: GISbased software that uses various trajectory statistical analysis methods to identify potential sources from long-term air pollution measurement data," Environmental Modelling \& Software, vol. 24, no. 8, pp. 938-939, 2009.

[27] I. Hwang and P. K. Hopke, "Estimation of source apportionment and potential source locations of $\mathrm{PM}_{2.5}$ at a west coastal IMPROVE site," Atmospheric Environment, vol. 41, no. 3, pp. 506-518, 2007.

[28] N. Liu, Y. Yu, J. He, and S. Zhao, "Integrated modeling of urban-scale pollutant transport: application in a semi-arid urban valley, Northwestern China," Atmospheric Pollution Research, vol. 4, no. 3, pp. 306-314, 2013.

[29] F. Karaca, I. Anil, and O. Alagha, "Long-range potential source contributions of episodic aerosol events to $\mathrm{PM}_{10}$ profile of a megacity," Atmospheric Environment, vol. 43, no. 36, pp. 5713-5722, 2009.

[30] A. V. Polissar, P. K. Hopke, and J. M. Harris, "Source regions for atmospheric aerosol measured at Barrow, Alaska," Environmental Science \& Technology, vol. 35, no. 21, pp. 42144226, 2001.

[31] Y.-K. Hsu, T. M. Holsen, and P. K. Hopke, "Comparison of hybrid receptor models to locate PCB sources in Chicago," Atmospheric Environment, vol. 37, no. 4, pp. 545-562, 2003.

[32] M. K. Christensen and J. M. Pringle, "The frequency and cause of shallow winter mixed layers in the Gulf of Maine," Journal of Geophysical Research, vol. 117, p. 1025, 2012.

[33] T. Liu, S. Gong, J. He et al., "Attributions of meteorological and emission factors to the 2015 winter severe haze pollution episodes in China's Jing-Jin-Ji area," Atmospheric Chemistry and Physics, vol. 17, no. 4, pp. 2971-2980, 2017.

[34] F. Chai, J. Gao, Z. Chen et al., "Spatial and temporal variation of particulate matter and gaseous pollutants in 26 cities in China," Journal of Environmental Sciences, vol. 26, no. 1, pp. 75-82, 2014.

[35] Y. Wang, Q. Ying, J. Hu, and H. Zhang, "Spatial and temporal variations of six criteria air pollutants in 31 provincial capital cities in China during 2013-2014," Environment International, vol. 73, pp. 413-422, 2014.
[36] C. Song, L. Wu, Y. Xie et al., "Air pollution in China: status and spatiotemporal variations," Environmental Pollution, vol. 227, pp. 334-347, 2017.

[37] J. Hu, L. Wu, B. Zheng et al., "Source contributions and regional transport of primary particulate matter in China," Environmental Pollution, vol. 207, pp. 31-42, 2015.

[38] W. Yang, G. Wang, and C. Bi, "Analysis of long-range transport effects on $\mathrm{PM}_{2.5}$ during a short severe haze in Beijing, China," Aerosol and Air Quality Research, vol. 17, no. 6, pp. 1610-1622, 2017.

[39] J. Hu, Y. Wang, Q. Ying, and H. Zhang, "Spatial and temporal variability of $\mathrm{PM}_{2.5}$ and $\mathrm{PM}_{10}$ over the North China plain and the Yangtze river Delta, China," Atmospheric Environment, vol. 95, pp. 598-609, 2014.

[40] D. Westerdahl, X. Wang, X. Pan, and K. M. Zhang, "Characterization of on-road vehicle emission factors and microenvironmental air quality in Beijing, China," Atmospheric Environment, vol. 43, no. 3, pp. 697-705, 2009.

[41] R.-J. Huang, Y. Zhang, C. Bozzetti et al., "High secondary aerosol contribution to particulate pollution during haze events in China," Nature, vol. 514, no. 7521, pp. 218-222, 2014.

[42] X. J. Deng, X. J. Zhou, D. Wu et al., "Effect of atmospheric aerosol on surface ozone variation over the Pearl River Delta region," Science China Earth Sciences, vol. 41, pp. 93-102, 2011.

[43] Z. S. Wang, Y. T. Li, T. Chen et al., "Analysis on diurnal variation characteristics of ozone and correlations with its precursors in urban atmosphere of Beijing," China Environmental Science, vol. 34, pp. 3001-3008, 2014, in Chinese.

[44] Y. L. Sun, Z. F. Wang, W. Du et al., "Long-term real-time measurements of aerosol particle composition in Beijing, China: seasonal variations, meteorological effects, and source analysis," Atmospheric Chemistry and Physics, vol. 15, no. 17, pp. 10149-10165, 2015.

[45] Y. Xin, G. Wang, and L. Chen, "Identification of long-range transport pathways and potential sources of $\mathrm{PM}_{10}$ in Tibetan plateau uplift area: case study of Xining, China in 2014," Aerosol and Air Quality Research, vol. 16, no. 4, pp. 10441054, 2016.

[46] M. R. Perrone, S. Becagli, J. A. Garcia Orza et al., "The impact of long-range-transport on $\mathrm{PM}_{1}$ and $\mathrm{PM}_{2.5}$ at a Central Mediterranean site," Atmospheric Environment, vol. 71, pp. 176-186, 2013.

[47] A. M. Dillner, J. J. Schauer, Y. H. Zhang, L. M. Zeng, and G. R. Cass, "Size-resolved particulate matter composition in Beijing during pollution and dust events," Journal of Geophysical Research: Atmospheres, vol. 111, pp. 769-785, 2006.

[48] Y. Sun, G. Zhuang, A. Tang, Y. Wang, and Z. An, "Chemical characteristics of $\mathrm{PM}_{2.5}$ and $\mathrm{PM}_{10}$ in haze-fog episodes in Beijing," Environmental Science \& Technology, vol. 40, no. 10, pp. 3148-3155, 2006.

[49] P. Xiang, X. Zhou, J. Duan et al., "Chemical characteristics of water-soluble organic compounds (WSOC) in $\mathrm{PM}_{2.5}$ in Beijing, China: 2011-2012," Atmospheric Research, vol. 183, pp. 104-112, 2017.

[50] L. Zhu, X. Huang, H. Shi, X. Cai, and Y. Song, "Transport pathways and potential sources of PM10 in Beijing," Atmospheric Environment, vol. 45, no. 3, pp. 594-604, 2011. 